\title{
Geology as a control on landslides on the Isle of Wight: an overview
}

\author{
G. O. Jenkins ${ }^{\mathrm{a}^{*}}$, C. Foster ${ }^{\mathrm{a}} \&$ P. M. Hopson ${ }^{\mathrm{a}}$ \\ ${ }^{\mathrm{a}}$ British Geological Survey, Keyworth, Nottingham, NG12 5GG \\ * Corresponding author, Email: gjenkins@ bgs.ac.uk, Tel: +44(0)115 9363128, Fax: \\ $+44(0) 1159363200$
}

\begin{abstract}
The Cretaceous and Palaeogene sedimentary rocks that crop out on the Isle of Wight are highly prone to landsliding and the island offers an important field laboratory wherein to investigate a number of the different types of failure. Many of these landslides represent a significant engineering hazard, with several urban areas requiring remedial work and planning constraints (e.g. The Undercliff and Seagrove Bay) to aid development. Previous studies have thoroughly investigated the major landslides in the Undercliff area around Ventnor and presented a mechanism for that massive failure. This overview of the landslides throughout the Isle of Wight by the British Geological Survey was completed as part of the multidisciplinary survey of the surface geology, structure, geophysical response and offshore interpretations of the island between 2007 and 2010. The survey has collected new observational data on the extensive coastal landslides, as well as the distribution, nature and mechanism of failure of the lesser-studied inland examples.
\end{abstract}

Keywords: Landslides, Isle of Wight, Cretaceous, Palaeogene, coastal erosion.

\section{$1 \quad$ Introduction}

The Cretaceous and Palaeogene strata of the Isle of Wight are mainly composed of relatively soft, often poorly lithified sedimentary rocks, the nature of which makes them highly susceptible to landsliding. These susceptible units are interbedded with more competent layers that affect the style of the failure by providing a natural 'reinforcement' of the stratal units during failure. Slope instability is exacerbated at the coast where marine erosion unloads the toes of cliffs leading to cliff failure and sequential failure within existing landslides. Extensive landslides occuring inland, for example on the slopes of the southern chalk downs, are the result of a complex interrelationship between the strata, geomorphological development, palaeoclimate and climate, and groundwater. Here the removal of toe debris is slow and sporadic and the slides have a natural angle of stability. Together, these areas present a significant hazard to infrastructure on the island.

The studies of landslides affecting the Undercliff in Ventnor, Luccombe, and Seagrove Bay (e.g. Hutchinson, 1991; Hutchinson et al., 1991a; Hutchinson et al., 1991b; Moore et al., 2007; Winfield et al., 2007; Moore et al., 2010) have significantly improved the understanding of the nature and mechanisms of these landslides. However, there is much less discussion of significant failures elsewhere. Thus the purpose of the interdisciplinary survey of the island described in this paper has been to provide an overview of all other major failures. 
The existing British Geological Survey (BGS) 1:50 000 geological map of the Isle of one continuous landslide is shown extending approximately $25 \mathrm{~km}$ from Brook Bay on the south-west coast to Luccombe on the SE coast. These published landslide polygons were principally derived from inspection of aerial photographs and limited field inspections in the mid 1970s. The landslide survey by the BGS in 2007 and 2008 re-examined these large landslide areas and mapped them with greater precision, more accurately reflecting the type of instability that is present as well as identifying additional areas affected by landslides. The survey has accounted for over 90 landslide affected areas. This paper highlights the widespread distribution of landslides on the Isle of Wight, documenting the extensive coastal landslides other than those around Ventnor, including the Palaeogene landslides along the northwest coast, and the lesser-studied inland landslides.

The exposed geology of the Isle of Wight spans a total of about 135 million years, including sediments deposited during the Cretaceous, Palaeogene and the Quaternary. No sediments are thought to have been deposited during the Neogene (Insole et al., 1998). A detailed account of the lithology, stratigraphy and depositional environment is beyond the scope of this paper, and the reader is referred to Insole et al., (1998) and the overview provided in Hopson (this issue). A simplified geological map, based on the current published map of the Isle of Wight is presented in Fig. 1 incorporating the landslides identified during the most recent survey.

In general flat-lying Cretaceous and Palaeogene strata are found to the south and north, respectively, of the central spine of the island within which both are incorporated into the complex steeply-dipping Isle of Wight structure. The internal architecture and lithology of these bedrock units underpin their response to erosion and slope stability and this will be discussed below. Thin, patchy and widely dispersed outcrops of Quaternary deposits overlie the bedrock, providing evidence for the complex climatic history that has affected the island. However, these limited outcrops belie the widespread affect of periglaciation on the both bedrock and superficial deposits alike. In some cases, the effects of periglaciation may also be significant in the development of slope failures, but this aspect of landslide development has not been well documented on the island.

The Isle of Wight has a varied geomorphology, including chalk downlands, coastal plains and large drowned estuaries (rias) (Booth \& Brayson, this issue) founded principally on the Palaeogene. As noted above the island is divided from east to west by a prominent chalk ridge that is the expression of the monocline, formed along the northern limbs of the asymmetric Brighstone and Sandown anticlines (which Hopson describes in detail in this issue). The structure forms the foundation of most of the inland steep slopes and also controls the formation of steep chalk cliffs at both ends of the island. With the exception of the low-lying estuaries the majority of the coastal sections around the island present cliffs of variable height reflecting the variably resistant strata and their response to coastal erosion. The majority of these cliffs carry landslides of one form or another and coastal instability and retreat is the dominant natural process. 
National Grid References quoted all fall within $100 \mathrm{~km}$ grid square SZ. The

\section{$2 \quad$ Landslide distribution and geology}

Each of the exposed geological units is susceptible to landsliding as the result of its own failure or as the result of failure of the underlying unit(s). Lithology provides the major control on the style and extent of landslide. The larger scale and most extensive landslides occur on the slopes around the Southern Downs (Fig. 1). Away from these chalk downs, inland landslides are rare. Smaller-scale landslides are widespread around most of the coast, and are only absent in low-lying areas such as Sandown Bay and along the northeast coastline. This may be a function of the greater incidence of coastal woodland helping to stabilise the low cliffs or indeed disguising the true degree of failure, and some notable examples of failure are known within wooded areas (e.g. Seagrove Bay).

\subsection{Wealden Group}

The Wealden Group, consisting of interbedded mudstones and sandstones, can be divided into the Wessex and Vectis formations (Table 1). The Wessex Formation is composed of a non-marine sequence comprising multicoloured, predominantly red, mudstones with subordinate sandstones. The Vectis Formation is principally composed of dark grey siltstones and mudstones which are thought to have been deposited in a shallow lagoonal environment. It is subdivided into three members: Cowleaze Chine, Barnes High Sandstone and Shepherd's Chine Members (Daley \& Stewart, 1979). Both formations are highly susceptible to landslide failures, particularly where they are exposed to storms on the southwest coast. The character of the failure is determined by the presence and thickness of sandstone units within both the Wessex and Vectis formations. This is illustrated in Fig. 2 using an example from the Wessex Formation along the Brook Undercliff. Here three basic types of failure can be identified (Zones A to C) associated with both formations. These are illustrated in Figs. 2 to 5.

Zone A represents whole cliff activity, with thinner sandstones being incorporated into landslides as rotated blocks and where the sandstones only act to limit failure when outcropping at beach level and the cliff above is relatively low (Fig. 3). Zone B represents cliffs where a thick competent sandstone acts as a natural revetment behind the beach or as a reinforcement to the cliff when above the beach level. The degree and inland extent of failure of the units above the competent sandstone is determined by the remaining height of the cliff. Failure of the sandstone leads to debris cones of material spilling onto the beach and abutting the sandstone unit (Fig. 4). In general, clay-rich units, when exposed below the competent sandstone, retain a steeper profile as they are frequently removed during storm events. In this scenario the sandstone generally fails by undercutting and block-failure. Zone $\mathrm{C}$ is illustrative of the cliff where no significant sandstone reinforcement is present and the whole cliff is active even where cliffs are low (Fig. 5). General observations indicate that the retreat of the cliffline is different within each of the zones; there is an increase of activity from Zone B into Zone A and the most severe retreat is associated with Zone C. 
Along the southwest coast, these zones can be most clearly seen between Roughland

is visible; similar features can be seen from Chilton Chine to Barnes High [43782 80666], from Barnes High along the coast toward Cowleaze Chine [44411 80020] and Shepherds Chine [46450 79815]. Here the Barnes High Sandstone (Fig. 6) forms the middle unit of three within the Vectis Formation. Landsliding is much more advanced (i.e. well developed backscar, bench and lobe features) where the whole cliff is composed of the Vectis Formation. Large scale rotational landslides and mudslides have developed in the Shepherds Chine Member (Fig. 7) beneath the Atherfield Clay Formation of the overlying Lower Greensand Group. These failures are mirrored at Compton Bay [37650 84175] where the Wealden Group and the Lower Greensand Group are eroding via a series of massive active landslides. The smallest of this group of landslides is destroying the car park at Shippards Chine [37715 84000]. This particular shallow, rotational failure, investigated by Bromhead et al. (2002), occurs within mudstone of the Wessex Formation and has a basal slide surface controlled by a bedding plane.

In Sandown Bay, on the southeast coast, landslides are present along the undefended section of coast between the landing stage near Yaverland [61207 85016] and the steep cliffs formed of higher strata at the eastern end of the bay [62726 85482]. The landslides along this section form a continuous belt of shallow mud and debris slides in mudstones of the Wessex Formation (Fig. 8). They pose a threat not only to users of the beach but also to the buildings that back onto the cliffs, some at a distance of only $60 \mathrm{~m}$. By analogy with failures on the southwest coast, this section is characterised by failures of the type in Zone $\mathrm{C}$, as discussed above.

\subsection{Lower Greensand Group}

The Lower Greensand Group (Table 1) is dominated by mainly sand lithologies and ranges from sandy mudstones of the Atherfield Clay Formation, to unconsolidated sands, siltstones, mudstones and limestones of the Sandrock Formation. The Monks Bay Sandstone Formation comprises course ferruginous sands and grits whilst the Ferruginous Sands Formation is highly variable with sandy clays, glauconitic sands pebble beds, siltstones and mudstones. Strata within the group are frequently subject to landsliding where it forms outcrop at the coast. The Lower Greensand Group is also involved with, but not necessarily the causal feature of, inland landsliding.

The largest landslide complex in Compton Bay [37132 84921] involves the Atherfield Clay Formation and most of the outcrop of the Ferruginous Sands Formation. Landsliding decreases in intensity as dips increase to the north-northwest into the Brighstone Anticline. The failure is within the Atherfield Clay Formation and probably in the upper part of the underlying Vectis Formation. The overlying Sandrock and Monks Bay Sandstone formations only appear to be susceptible to isolated rockfalls at this location. This probably results from the oblique orientation of the bedding strike of the units with respect to the cliff-line and their steep dip into the cliffs. The largest of the failures in the Compton Bay landslide complex is approximately $750 \mathrm{~m}$ wide. Local degradation and vegetation (Fig. 9) indicate the antiquity of parts of the landslide. However, rotated blocks, ponding and flows indicate more recent activity. 
The stratigraphical sequence in Compton Bay is repeated on the other side of the island in Sandown Bay, but here the beds dip at approximately $10^{\circ}$ to the northnortheast. At Red Cliff [62360 85380] shallow translational landslides in the Wessex and Vectis formations (see above) give way to a much larger landslide complex developed in the Atherfield Clay Formation. The boundary of the Vectis and Atherfield Clay formations forms a zone that is subject to large scale landsliding, as at Cowleaze and Shepherd's Chine. Translational and rotational landsliding, and isolated mudslides are present and large rotated blocks were observed at the time of the survey in 2007 (Fig. 10). The landslide complex extends up to $150 \mathrm{~m}$ inland and is approximately $115 \mathrm{~m}$ wide at beach level. It is known to have been almost continuously active since at least 1912 (Hutchinson, 1965).

Considerably more complex failures occur within the Lower Greensand Group on the coast at Chale Bay from Blackgang Chine [48400 76800] to Walpen Chine [46800 78200]. Here a bench has developed mid way up the cliff in the Ferruginous Sands and Sandrock formations. Seepage erosion is taking place because of the presence of clay aquitards within the sequence. Water movement along the top of the aquitards leads to the undermining of material, leading to rock falls. Once on the bench the landslide debris fails in a series of compound slides moving seaward. This process produces a cliff top retreat rate that is more rapid than the marine erosion at the base of the cliff, leading to the formation of the bench feature (Fig. 11) (Insole et al., 1998).

\subsection{Selborne Group}

The Selborne Group consists of dark blue-grey silty clays of the Gault Clay Formation passing transitionally upwards into glauconitic siltstone and fine-grained sand and sandstone (with bands of calcareous and siliceous concretions) of the Upper Greensand Formation. The Selborne Group is the controlling geological factor in the landsliding of the Undercliff at Ventnor. This is an area that has become internationally renowned as an example of good practice in landslide investigation and remediation. The area has been the subject of two large conferences to demonstrate best practice in dealing with landslide problems (McInnes and Jakeways, 2002, McInnes et al., 2007). There is a large volume of documentation relating to the area (Hutchinson, 1991, Hutchinson et al., 1991a, Hutchinson et al., 1991b, Moore et al., 2007 and Moore et al., 2010) and so the area is not discussed in detail here. However the area is geologically similar to the Luccombe area discussed below.

The ancient landslide complex at Luccombe Chine [58090 79370] is very similar to that at Ventnor. This landslide is known to have been reactivated in the $19^{\text {th }}$ and $20^{\text {th }}$ Centuries and currently poses a potential threat to Luccombe Village. Lee and Moore (1989) divided the landslide into 3 separate systems: ancient landslide units; landsliding within a contemporary degradation zone; and erosion and landsliding of modern sea cliffs. Ancient landsliding is still visible, represented by the degraded multiple rotational blocks present above the village (Fig. 12). The back scars of these features are within the Upper Greensand Formation, whilst it is postulated that the shear surfaces lie within an upper clay-rich layer in the underlying Gault Formation (Lee and Moore, 1989). Since the 1950s, reactivation of the contemporary degradation zone has led to ground movements within Luccombe Village and the destruction of several houses. Luccombe Village itself is built on a relict landslide 
feature which has been reactivated due to cliff recession unloading the slope. Construction of the houses, as well as drainage from them, is considered to have contributed to this instability. Alteration of ground conditions, combined with intense rainfall events, have led to periodic, major reactivations taking place. Demolition of at least two houses was necessary after movements in 1987 and 1988 (Lee and Moore, 1989).

Large-scale inland landslides are also associated with the Selborne Group, particularly on the south-western and northern margins of the Southern Downs. The hillsides around the downs of St Catherine's [49360 78430], Appuldurcombe [53610 80450], St Martin's [55570 80600], and Shanklin [57015 80165] all exhibit deep-seated rotational landslides extending for several hundred metres across and down slope. Large benches and blocks of Upper Greensand have failed and rotated on the underlying Gault Formation. Prominent cliffs have formed in the upper portion of the hillsides where backscars have formed in the Upper Greensand Formation (Fig.13). Most of these features appear stable, but smaller scale failures within the broader landslide zone display remarkably fresh landforms and they still occur depending on a number of factors. Intense rainfall events are probably the most important, increasing seepages within the chaotically deposited slip material and resulting in upslope failures. The age of the larger landslide features is open to speculation but they probably fall in the 'ancient landslide' category adopted by Lee and Moore (1989). Very similar relict landslides occur in the same geological setting (e.g. Hopson, 1999) near the Hampshire/Sussex border around the western closure of the Weald and here they are considered to be Late- or immediately post-Devensian in age. They are considered to have resulted from periglacial unlocking and remobilisation of groundwater during the climatic amelioration at the end of the Devensian. This resulted in high moisture content and pore pressures as well as spring-head erosion at the base of the Upper Greensand. This is envisaged by the authors as the mechanism of failure for these landslides on the Isle of Wight.

\subsection{White and Grey Chalk Subgroups}

The White and Grey Chalk Subgroups comprise parts of the previously named Upper, Middle and Lower Chalk. The Grey Chalk Subgroup is a clayey chalk without flints while the White Chalk Subgroup is a chalk with flints along with some discrete marl seams. The chalk subgroups form steep, high cliffs between Compton Bay and the Needles [28965 84840] in the west and at Culver Cliff [463710 85395] in the east (Fig. 1). The cliffs in both areas are subject to falls of material. Some sliding is controlled by the presence of well-developed bedding and joint planes and the attitude of that bedding to the foreshore and erosion.

At Afton Down [36075 85580] in the west, failures in the chalk have required a major realignment of the A3055 Military Road. This important route across the island runs approximately $10-45 \mathrm{~m}$ from the edge of the $70 \mathrm{~m}$ high sea cliff. Fissuring in the weathered chalk at the top of the cliff was observed to run roughly parallel to the cliff edge during field work in 2007. At the top of the cliff, the beds dip steeply into the cliff ( $65^{\circ}$ towards the north), with widely spaced (1-2 m), low angled joints that are parallel to the slope. Failure occurs by translational movement along the shorewardfacing joint planes. Once the material has translated toward the edge of the cliff, fissures develop in the soil and rock mass, leading to toppling failures (Anon, 2007). 
Marine erosion at the site is also a significant factor leading to undercutting of the southern margins of Culver Cliff where it abuts Sandown Bay [6350 8550], although the fissuring does not appear to be as advanced. Little work has been conducted at this site as it does not directly affect any infrastructure. Photographs collected during an airborne geophysics survey by the BGS in September 2008 reveal the presence of large tension cracks above Tennyson Down at the western end of the island, suggesting that further failures along this section are also likely (Fig.14).

The chalk that forms the headland in the south of Alum Bay [30000 85000] has a steep northerly dip into the bay with bedding planes being commonly undercut by wave-action. This difference in orientation (e.g. compared to Afton Down) results in failure on bedding planes rather than along joints. Typically, rock slides occur where the dip of the beds is approximately parallel to the topographic slope. In Alum Bay the chalk dips between $70-75^{\circ}$ to the north, whilst the cliff slopes at about $60^{\circ}$ to the north. It is possible that the movement includes both translational movement and falling (Fig.15).

\subsection{Lambeth, Thames, Bracklesham and Barton Groups}

The Reading Formation (Lambeth Group) is composed of predominantly mottled red and purple clays with a basal conglomerate and sand. It outcrops in the west at Alum Bay and in the east at Whitecliff Bay [463975 85830]. In both areas bedding is vertical and the entire formation is subject to mudsliding (Fig. 16). The landslide in Alum Bay is reported to have originally formed around the turn of the $20^{\text {th }}$ Century (Bromhead, 1979) and is most active between winter and early spring when the steep slopes at its head become saturated due to higher rainfall levels. This causes the slope to become unstable and fail as a mudslide, resulting in the formation of lobate toes extending onto the beach (Bromhead, 1979). The toe area of the mudslide is subject to marine erosion and is often eroded back to the cliff line during summer months, when rainfall levels are generally lower and the slide is less active.

The Thames Group is represented by the London Clay Formation which consists of a series of upward coarsening units composed of clays, silts and sands. The pattern of landsliding in the London Clay Formation is similar to that in the Reading Formation. Narrow gullies in both Alum Bay and Whitecliff Bay have formed between the vertical strata as a result of the removal of material by mudsliding, although at both localities the slides are not as active or advanced as those in the Reading Formation.

The Bracklesham Group is divided into six formations on the western side of the island and four formations on the eastern side (Table 2). They generally consist of a rhythmic sequence of glauconitic sands and clays at the base, succeeded by interbedded clays, silts, and sands and also lignites. The Barton Group is divided into four formations (Table 2) which are composed mainly of sands with subordinate clays and silts The Bracklesham Group and Barton Group in Alum Bay are not generally susceptible to widespread landsliding, but are susceptible to shallow rotations, mudslides and gullying erosion. In Whitecliff Bay, a failure in the Wittering Formation (Bracklesham Group) has occurred. This shallow mudslide is developed in vertically-bedded laminated sandy muds and in 2007 had receded to within $20 \mathrm{~m}$ of a caravan park. 


\subsection{Solent Group}

The Solent Group is divided into three formations; the Headon Hill Formation is divided from the younger Bouldnor Formation by the Bembridge Limestone Formation. The Headon Hill Formation is separated into nine members (see Fig. 8 in Hopson, this issue) which are comprised of clays, sandy clays and limestones. The Bembridge Limestone Formation consists of limestone and marly limestone with shells, including peloidal limestone and calcrete with calcareous clay interbeds. The Bouldnor Formation comprises three members: the Bembridge Marls Member which is composed of grey-green clays and sandy clays, the Hamstead Member consisting of green clays and black organic sediments and the Cranmore Member is represented by shelly clays. The group contains interbedded units that may enhance or inhibit potential failure. For example where sand units are present they may carry groundwater or offer a conduit for surface run-off, or where thicker limestone units are present they may provide reinforcement to the cliff face. Examples of the types of landslide present are given below but there is a need for further study to provide a comprehensive appraisal of this group throughout the island.

Outcrops of the Headon Hill Formation are subject to active erosion and landsliding, especially along the coastline from Fort Albert [33010 89090] to Yarmouth [34715 89750]. Shallow mudslides and flows are currently eroding the cliffs at Fort Victoria [33615 89630], forming embayments and lobes. Larger landslides are also present on this stretch of coastline (Fig. 17). In the lower sections of the cliff, landsliding is occurring through failure at relatively shallow depth whilst higher in the cliff, deepseated rotational landslides result in recession of the cliff line.

Within the wooded areas of Fort Victoria Country Park [33630 89580] there is a conspicuous landslide topography of degraded hummocks and ridges. These relict features indicate that there has previously been a more pervasive period of landsliding along this section of coastline and that it was more advanced than the shallow failures that are currently active within the cliff. It is likely that these ancient landslides formed when sea level was lower (Lambeck, 1997) than the present day, and their slip planes are thought to propagate beneath current beach level. Evidence for this largerscale ancient activity is present in the beach in front of the cliff. The Fishbourne Beds and Osbourne Member of the Headon Hill Formation, seen as horizontally-bedded units in the mid-cliff section, are also found on the beach platform as steeply-dipping rotated, back-tilted blocks (Fig. 18) indicating a buried slip plane at depth. Hutchinson and Bromhead (2002) also described a raft of Headon Hill Formation with vertical strata near to this site at Bouldnor Cliff [38810 90955].

Rotational landslides and mudslides are a feature of the Bouldnor and Hamstead [39845 91630] cliffs on the NW coast. The cliffs along this section of coastline are composed entirely of the Bouldnor Formation, which is weak and susceptible to marine erosion. The mudslides are thought to have been initiated at the turn of the $20^{\text {th }}$ Century and are seasonal (White, 1921). They appear to be controlled by high precipitation, high ground water levels and associated elevated pore water pressures (Bromhead, 1979). Denness (1970) suggested that the presence of a syncline behind Hamstead Cliffs plunging toward the sea provides a directed pathway for groundwater towards the cliff, resulting in increased activity at this site. 
Another control on the type and activity of landsliding along this section of coastline the Bouldnor Formation. To the east of Bouldnor the Bembridge Limestone crops out at beach level; the increased resistance provided by the limestone at the base of the cliff reduces the rate of recession and decreases the activity and scale of mudsliding in the overlying Bouldnor Formation (Hutchinson, 1983). To the west of Bouldnor, the limestone is not exposed in the beach and this leads to increased marine erosion of the soft muds. The rate of erosion at the toe is greater than the rate of mudsliding, leading to an oversteepening of the cliffs. This, in turn, leads to the formation of deeperseated rotational landslides (Bromhead, 1979).

Landsliding of varying type, activity and age is present on the coast between Cowes [49580 96380] and Gurnard [47240 95455]. Large, deep-seated, ancient, degraded landslides form many of the coastal slopes in this area. Evidence for modern landsliding is also apparent in both the developed and undeveloped areas. Houses show evidence of displacement and settlement and cracks commonly appear in the road. Heaving of the landslide toe is evident along the Esplanade. Further inland along the coastal slope, benches and fresh scarps provide evidence for more recent movement (Halcrow, 2000). Erosion rate at the toe exceeding the cliff-fall material replenishment rate in this area has led to active recession of the backscar, as indicated by the loss of part of a garden from a private residence on the cliff at Gurnard during the winter of $2007 / 08$.

Landslide activity at Seagrove Bay [63130 91070], on the northeast coast presents a significant hazard to local infrastructure. There is a long history of property damage due to ground movement (Winfield et al., 2007). The whole of the slope behind the bay is critically stable, i.e. it is close to failure and has a factor of safety very close to one. A change in the environmental conditions, such as an increase in the level of the local water table, or removal of support from the toe of the landslide by beach erosion, could result in failure of the slope.

\section{Discussion}

The majority of the geological strata that crop out on the Isle of Wight are susceptible to landsliding, either directly or indirectly. The geological structure of the island also influences landslide frequency, with the steeply-dipping strata around the central axis (Fig. 1) facilitating a greater incidence of landsliding. However landslides are most common around the coast. Ancient, advanced landslides are present on the slopes of the Southern Downs. They formed during periglacial conditions but are currently inactive. The stratigraphy here is similar to that of the active landslide complex at Ventnor, but the slides are stable because no material is removed from the toe. Therefore it is coastal erosion that is the primary causal factor of active landsliding on the island.

Coastal aspect almost certainly has an influence on landslide frequency around the island. Taking the example of the Wealden Group strata that crop out in the southern half of the island, landslide frequency and thus coastal recession is likely to be highest along the south west coast between The Needles [29000 84825] and St Catherine's Point [49850 75265] where the full effect of storms and a wave fetch of several thousand kilometres impact on the cliffs. Conversely in Sandown Bay, with a more 
sheltered south-easterly aspect, the cliffs are more protected from storms and wave energy is much lower. Therefore the frequency of landslides and coastal recession is likely to be lower.

Cliff height influences landslide style due to the accommodation space, and therefore mass of material, available for a landslide to occur (i.e. higher cliffs lead to larger, more advanced landslides). The landsliding along the coastal section between Compton Chine [36780 85180] and Hanover Point [37940 83770] provides a good example of this. A large, relatively deep-seated, multiple, rotational landslide has developed where the cliffs are highest at the western end of the bay. As the cliffs become lower along the coast to the south east, landslides are less advanced and consist of shallow rotations and mudflows due to less accommodation space being available.

Extensive, active landslides are present along the northwest coast of the island. This area of the island is currently underdeveloped and as a result there are very few published studies of the landslides. With a likely future increase in population and the associated increasing pressure on the landscape through residential and tourism infrastructure, there is a need for more detailed understanding of the engineering geological properties of the strata present along this stretch of coastline, and the failure mechanisms of the landslides, to ensure sustainable development of the area.

Climate change forecasts such as an increase in the frequency and intensity of storm events and sea level rise (Jenkins et al., 2009), will have serious implications for the unstable coast around the Isle of Wight. The frequency and magnitude of landslides are likely to increase leading to an increased rate of coastal recession. Higher rainfall levels may also lead to the reactivation of the currently stable inland landslides around the Southern Downs. Fresh scarps observed during the 2007 survey provide evidence of more recent, small-scale movement and suggest that the larger, ancient landslides could reactivate if rainfall event volumes and frequencies become greater in the future.

\section{Conclusions}

Landslides on the Isle of Wight are highly variable. They include large deep-seated multiple rotations associated with the Downs of Appuldurcombe, St Catherine's, St Martin's and Shanklin, and shallower rotations and flows around the coast. The majority of geological formations present on the Isle of Wight are susceptible to landsliding. Many of the formations are composed of soft, poorly lithified sediments making them highly susceptible to coastal erosion. Erosion removes support from the base of the cliff and leads to subsequent failure. The widespread distribution of landslides present potentially significant engineering and infrastructure problems; notable large and active landslides occur at Ventnor, at Luccombe and Seagrove Bay and along the Military Road at Afton Down.

The style and extent of landslides on the island is controlled by a complex interplay of several factors: coastal position; the potential for unloading of the toe by marine erosion; the degree of natural reinforcing within the lithological components of the unit; the incidence of that reinforcement in respect of its position within the landform concerned; geological structure; the incidence of significant climatic events (intense 
storm activity and rising sea level). Landsliding is most frequent and active around the coast due the effects of coastal erosion.

The northwest coastline of the island is a key target for future landslide research.

Focussed testing of engineering geological properties, and more detailed analysis of the mechanisms of failure along this coast would ensure sustainable future development.

If forecasts of climate change prove to be correct, then higher sea levels and increased storm intensity and frequency are likely to exacerbate the frequency and scale of landsliding on the Isle of Wight.

\section{Acknowledgements}

The authors would like to thank Anthony Cooper, Helen Reeves, Philip Wilby and Chris Thomas for constructive advice and guidance during the drafting of this paper. Gareth Jenkins, Claire Foster and Peter Hopson publish with the permission of the Executive Director of the British Geological Survey (NERC). 


\section{References}

Anon, 1993. Low-rise buildings on shrinkable clay soils: Part 1, Digest 240. Building Research Establishment. Watford.

Anon 2007. International conference on Landslides and Climate Change- Challenges and Solutions. Field Study Notes. Ventnor, Isle of Wight, 21-24 ${ }^{\text {th }}$ May 2007.

Bell, F. G. 2000. Engineering properties of soils and rocks. $4^{\text {th }}$ Edition. Blackwell, Oxford.

Booth, K. A. and Brayson, J. 2011. Geology, landscape and human interactions: Examples from the Isle of Wight. Proceedings of the Geologists' Association. 122, XXX-XXX.

Bromhead, E. N. (1979) Factors Affecting the Transition Between the Various Types of Mass Movement in Coastal Cliffs Consisting Largely of Over-Consolidated Clay, with Special Reference to Southern England, Quarterly Journal of Engineering Geology. 12(4), 291-300.

Bromhead, E. N., Ibsen, M-L., Papanastassiou, X and Zemichael, A.A. 2002. Threedimensional stability analysis of a coastal landslide at Hanover Point, Isle of Wight. Quarterly Journal of Engineering Geology \& Hydrogeology. 35(1), 79-88.

British Geological Survey. 1976. Isle of Wight. Special Sheet. Part of sheets 330, 331. Sheets 344, 345. Drift Edition. Ordnance Survey, Southampton.

Chadwick, A.1986. Extension tectonics in the Wessex Basin, southern England. Journal of the Geological Society, London. 143, 465-488.

Daley, B. and Stewart, D. J. 1979. Week-end field meeting: the Wealden Group in the Isle of Wight 17-19 June 1977. Proceedings of the Geologists' Association. 90, 5154.

Denness, B. 1970. A note on the landslip at Hampstead cliff, Isle of Wight. Engineering Geology Group Report WN/EG/70/004. British Geological Survey.

Halcrow Group Ltd, 2000. Cowes to Gurnard coastal slope stability study: ground behaviour assessment. Isle of Wight Council.

Hooker, J. J., Grimes, S. T., Mattey, D. P., Collinson, M. E. and Sheldon, N. D. 2009. Refined correlation of the UK Late Eocene-Early Oligocene Solent Group and timing of its climate history. In Koeberl, C and Montanari, A. (eds), The Late Eocene Earth Hothouse, Icehouse and Impacts: The Geological Society of America Special Paper 452, 179-195.

Hopson, P.M., 1999. Geology of the Fareham and Portsmouth district. Sheet Description of the British Geological Survey, Sheet 316 and part of 331 (England and Wales).

Hopson, P. M. 2011. The geological history of the Isle of Wight: an overview of the 'diamond in Britain's geological crown'. Proceedings of the Geologists' Association 122, XXX-XXX.

Hutchinson, J. N. 1965. A reconnaissance of coastal landlslides in the Isle of Wight. Building Research Station Note No. EN 11/65. Department of Scientific and Industrial Research. Watford. 
Hutchinson, J. N. 1983. A Pattern in the Incidence of Major Coastal Mudslides, Earth Surface Processes and Landforms. 8, 391-397.

Hutchinson, J. N. 1991. The landslides forming the South Wight Undercliff. In Chandler, R. J. (eds). Slope Stability Engineering: Developments and Applications. Proceedings of the International Conference on Slope Stability Organized by the Institution of Civil Engineers and held on the Isle of Wight on 15-18 April 1991 (ed. R.J. Chandler), Thomas Telford, London. 157-68.

Hutchinson J. N., Brunsden D. and Lee E. M. 1991a. The geomorphology of the landslide complexes at Ventnor, Isle of Wight. In: Chandler R.J. (ed.) Slope Stability Engineering, Developments and applications. Proc. of the Int. Conf. on Slope Stability organised by the ICE, Shanklin, Isle of Wight. 213-218.

Hutchinson, J. N., Bromhead, E. N. and Chandler, R. J. 1991b. Investigations of the landslides at St Catherine's Point, Isle of Wight. In Chandler, R. J. (ed). Slope Stability Engineering: Developments and Applications. Proceedings of the International Conference on Slope Stability Organized by the Institution of Civil Engineers and held on the Isle of Wight on 15-18 April 1991, Thomas Telford, London. 169-179.

Hutchinson, J. N. and Bromhead, E. N. 2002. Isle of Wight Landslides. In McInnes, R. G. and Jakeways, J. (eds), Instability Planning and Management. Proceedings of the International Conference. Ventnor, Isle of Wight, UK. 20-23rd May 2002. Thomas Telford.

Insole, A., Daley, B. and Gale, A. 1998. The Isle of Wight. Geologists Association Guide No.60. The Geologists Association.

Jenkins, G. J., Murphy, J. M., Sexton, D. M. H., Lowe, J. A., Jones, P. and Kilsby, C. G. (2009). UK Climate Projections: Briefing report. Met Office Hadley Centre, Exeter, UK.

Lambeck, K. 1997. Sea-level change along the French Atlantic and Channel coasts since the time of the Last Glacial Maximum. Palaeogeography, Palaeoclimatology, Palaeoecology. 129, 1-22.

Lee, E. M. and Moore, R. 1989. Report on the study of landsliding in and around Luccombe Village. Department of the Environment.

McInnes, R. G. \& Jakeways, J. 2002. Instabililty: Planning and Manangement. Seeking sustainable solutions to ground movement problems. Proceedings of the international conference organised by the Centre for the Coastal Environment, Isle of Wight Council, Ventnor, Isle of Wight, UK, 20-23 May 2002.

McInnes, R. G., Jakeways, J., Fairbank, H. and Mathie, E. 2007. Landslides and Climate Change: Challenges and Solutions. Proceedings of the International Conference on Landslides and Climate Change, Ventnor, Isle of Wight, UK, 21-24 May 2007.

Moore, R., Turner, M. D., Palmer, M. J. and Carey, J. M. 2007. The Ventnor Undercliff: Landslide model, mechanisms and causes, and the implications of climate change induced ground behaviour and risk. In McInnes, R., Jakeways, J, Fairbank, H. and Mathie, E. (eds), Landslides and Climate Change, Challenges and Solutions. Proceedings of the International Conference on Landslides and Climate Change, Ventnor, Isle of Wight, May 21-24 2007. 365-376. Thomas Telford. 
Moore, R., Carey, J. M. and McInnes, R. G. 2010. Landslide behaviour and climate change; predictable consequences for the Ventnor Undecliff, Isle of Wight. Quarterly Journal of Engineering Geology \& Hydrogeology. 43(4), 447-460.

Preece R. C., Scourse, J. D., Houghton, S .D., Knudsen, K. L. and Penney, D. N., 1990. The Pleistocene sea-level and neotectonic history of the eastern Solent, southern England. Philosophical Transactions of the Royal Society. B328, 425-477.

Radley, D. 2006. A Wealden guide II: the Wessex sub-basin. Geology Today. Vol 22 Issue 5. 187-193.

White H.J.O. 1921. A short account of the geology of the Isle of Wight. Memoir of the Geological Survey of Great Britain (England and Wales). HMSO.

Winfield, P., Moses, E. and Woodruff, M. 2007. Combining slope stability and coast protection at Seagrove Bay on the Isle of Wight. In McInnes, R., Jakeways, J, Fairbank, H. and Mathie, E. (eds), Landslides and Climate Change, Challenges and Solutions. Proceedings of the International Conference on Landslides and Climate Change, Ventnor, Isle of Wight, May 21-24 2007. 365-376. Thomas Telford. 


\section{Figure captions}

Fig. 1. Simplified geological map of the Isle of Wight, with selected geological dip readings. See Tables 1 and 2 for detailed stratigraphy. New landslide areas mapped during the 2007 survey marked in orange. Geological data, British Geological Survey (C) NERC. OS topography (C) Crown Copyright. All rights reserved. BGS $100017897 / 2011$.

Fig. 2. Location of sandstones and their influence on landslides between Chilton Chine and Roughlands (Modified from Insole et al., 1998).

Fig. 3. Active landsliding near Chilton Chine (Fig. 2, Zone A). P760896.

Fig. 4. Presence of debris cones below a massive sandstone bed in the cliff at Sudmoor Undercliff (Fig. 2, Zone B). P769944.

Fig. 5. Retreat of cliff line through active landsliding at Roughland Cliff, near Brook (Fig. 2, Zone C). P769945.

Fig. 6. Failures in the Vectis Formation of the Wealden Group. P769946.

Fig. 7. Failures in the Shepherds Chine Member, Vectis Formation, east of Shepherds Chine. P760858.

Fig. 8. Landsliding at Red Cliff, Sandown Bay. P769942.

Fig. 9. View across the large landslide complex in Compton Bay. P760901.

Fig. 10. Rotated block (Ferruginous Sands Formation) in the beach at Yaverland. P769933.

Fig. 11. Bench feature between Walpen Chine and Blackgang Chine. P769966.

Fig. 12. View across Luccombe Coombe toward Knock Cliff. P769442.

Fig. 13. Backscars composed of the Upper Greensand Formation, St Catherine's Down. P769458.

Fig. 14. Tension cracks above Tennyson Down which could lead to large scale failures. P769938.

Fig. 15. Failure in steep chalk cliffs at White Cliffs, Alum Bay. P769937.

Fig. 16. Mudslide in the Reading Formation, Whitecliff Bay. P769939.

Fig. 17. Recent landslide at Fort Victoria. P769500.

Fig. 18. Steeply dipping bedded raft of Headon Hill Formation embedded in the beach at Fort Victoria. P769941. 


\section{Table captions}

Table 1. The Cretaceous strata at outcrop on the Isle of Wight.

Table 2. The Palaeogene strata at outcrop on the Isle of Wight. 
Table 1. The Cretaceous strata at outcrop on the Isle of Wight

\begin{tabular}{|c|c|}
\hline Group or Subgroup & Formation \\
\hline \multirow{7}{*}{ White Chalk Subgroup } & Portsdown Chalk Formation \\
\hline & Culver Chalk Formation \\
\hline & Newhaven Chalk Formation \\
\hline & Seaford Chalk Formation \\
\hline & Lewes Nodular Chalk Formation \\
\hline & New Pit Chalk Formation \\
\hline & Holywell Nodular Chalk Formation \\
\hline \multirow{2}{*}{ Grey Chalk Subgroup } & Zig Zag Chalk Formation \\
\hline & West Melbury Marly Chalk Formation \\
\hline \multirow{2}{*}{ Selborne Group } & Upper Greensand Formation \\
\hline & Gault Formation \\
\hline \multirow{4}{*}{ Lower Greensand Group } & Monk's Bay Sandstone Formation \\
\hline & Sandrock Formation \\
\hline & Ferruginous Sands Formation \\
\hline & Atherfield Clay Formation \\
\hline \multirow{2}{*}{ Wealden Group } & Vectis Formation \\
\hline & Wessex Formation \\
\hline
\end{tabular}


Table 2. The Palaeogene strata at outcrop on the Isle of Wight

\begin{tabular}{ccc}
\hline \multirow{2}{*}{ Group } & \multicolumn{2}{c}{ Formation } \\
\hline \multirow{3}{*}{ Solent Group } & \multicolumn{2}{c}{ Bouldnor Formation } \\
\cline { 2 - 3 } & \multicolumn{2}{c}{ Bembridge Limestone Formation } \\
\cline { 2 - 3 } Barton Group & Headon Hill Formation \\
\cline { 2 - 3 } & Becton Sand Formation & Becton Sand Formation \\
\cline { 2 - 3 } & Barton Clay Formation & Barton Clay Formation \\
\cline { 2 - 3 } & Boscombe Sand Formation \\
\hline \multirow{3}{*}{ Bracklesham Group } & WEST & EAST \\
\cline { 2 - 3 } & Branksome Sand Formation & Selsey Sand Formation \\
\cline { 2 - 3 } & Marsh Farm Formation & Marsh Farm Formation \\
\cline { 2 - 3 } & Wittering Formation (Upper) & Wittering Formation \\
\cline { 2 - 3 } & Poole Formation (Lower) \\
\cline { 2 - 3 } & Wittering Formation (Lower) \\
\hline
\end{tabular}


Click here to download high resolution image

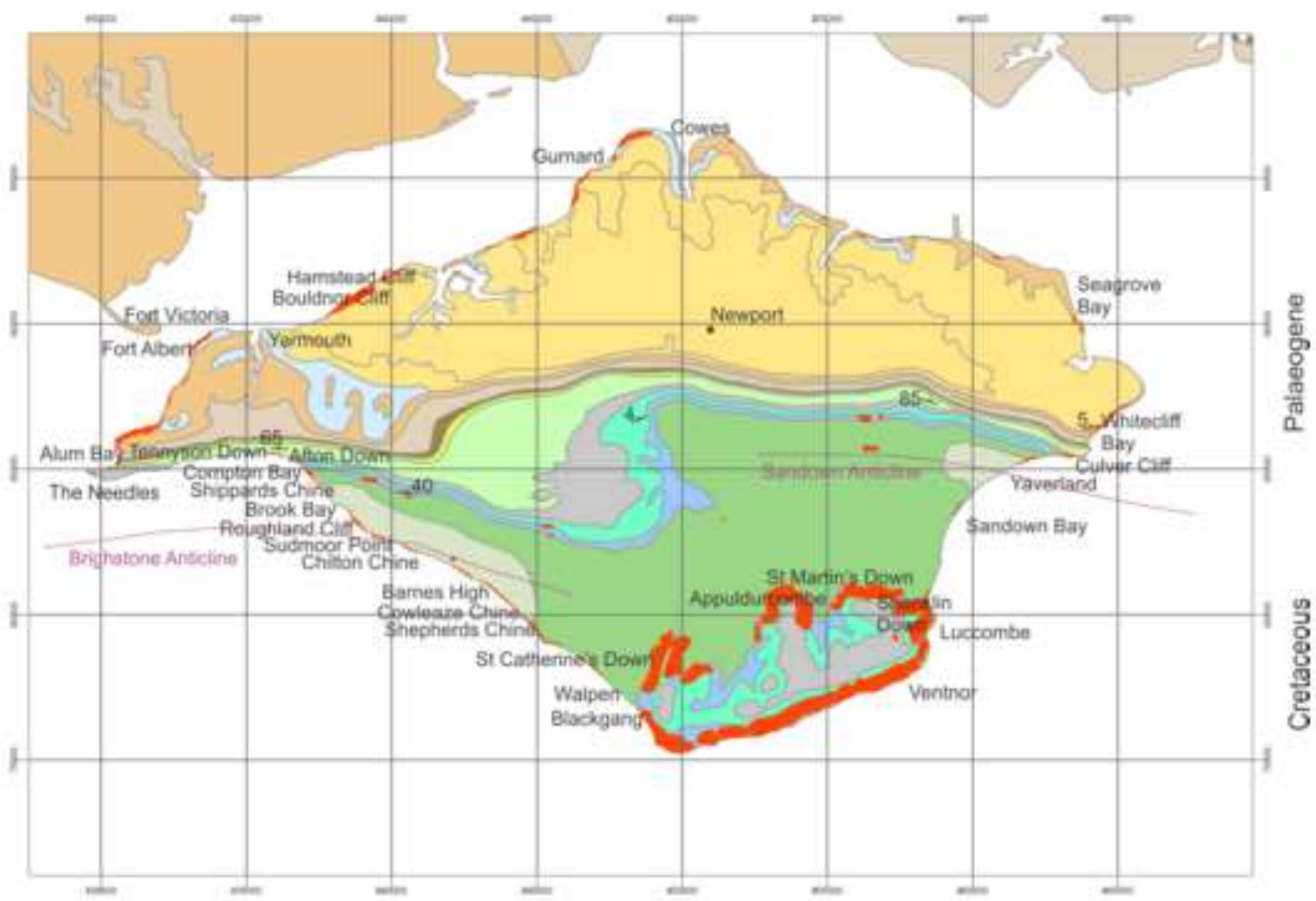

\section{Legend}

$\square$ Bouldnor Formation

Bembridge Limestone Formation

胥 $\square$ Headon Hill Formation

Barton Group

Bracklesham Group

Thames Group

Lambeth Group

\section{White Chalk Subgroup}

Grey Chalk Sutgroup

Upper Greensand Formation

Gault Formation

Lower Greensand Group

Wealden Group 
Click here to download high resolution image

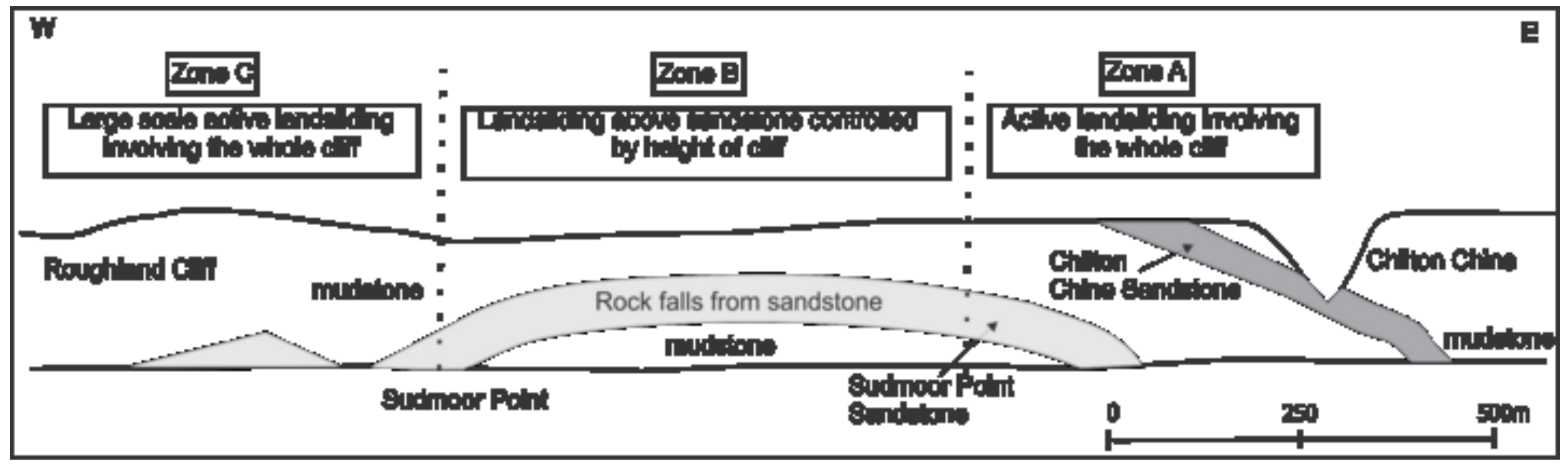

\section{Click here to download high resolution image}


Click here to download high resolution image

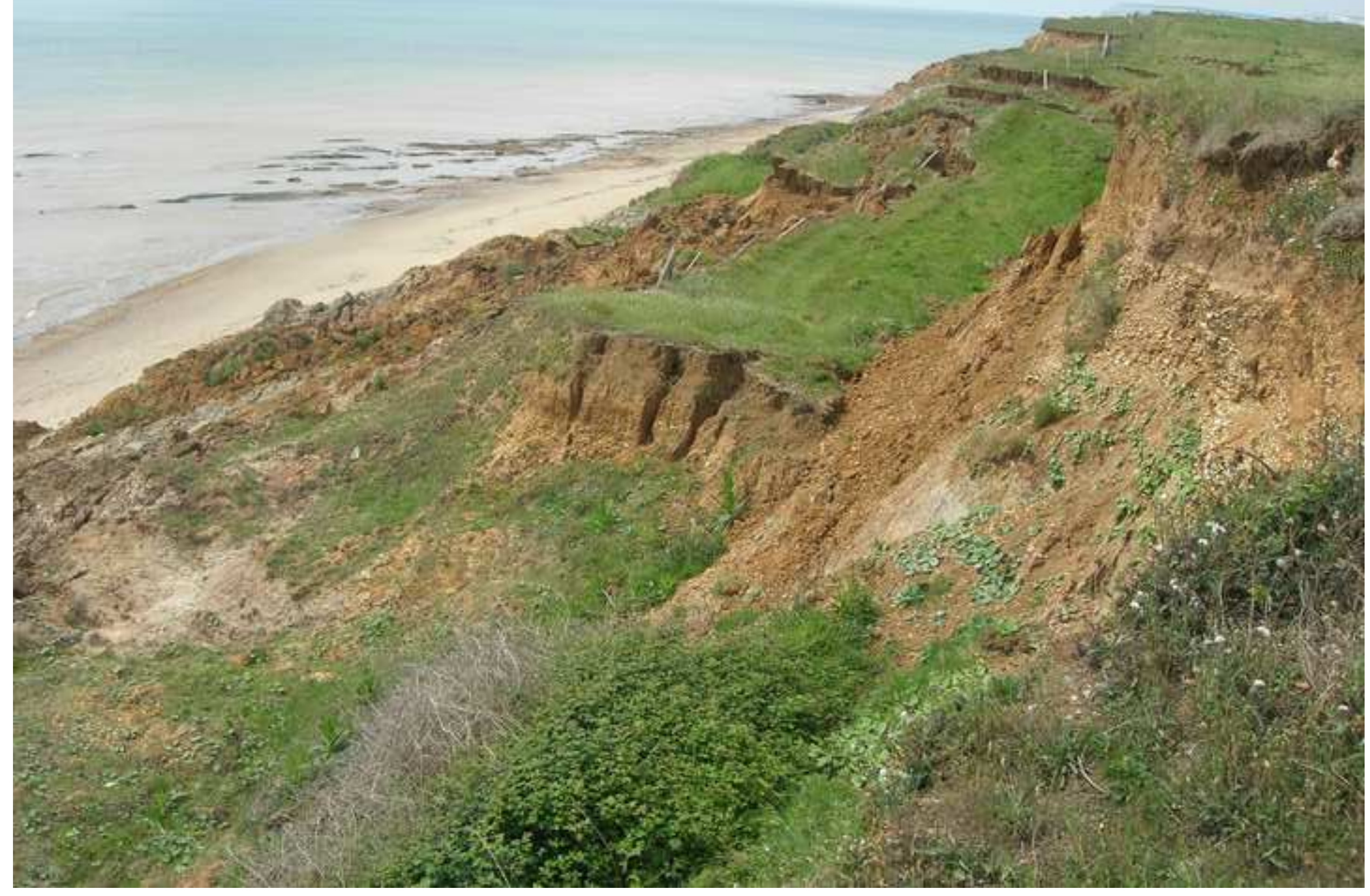


Click here to download high resolution image

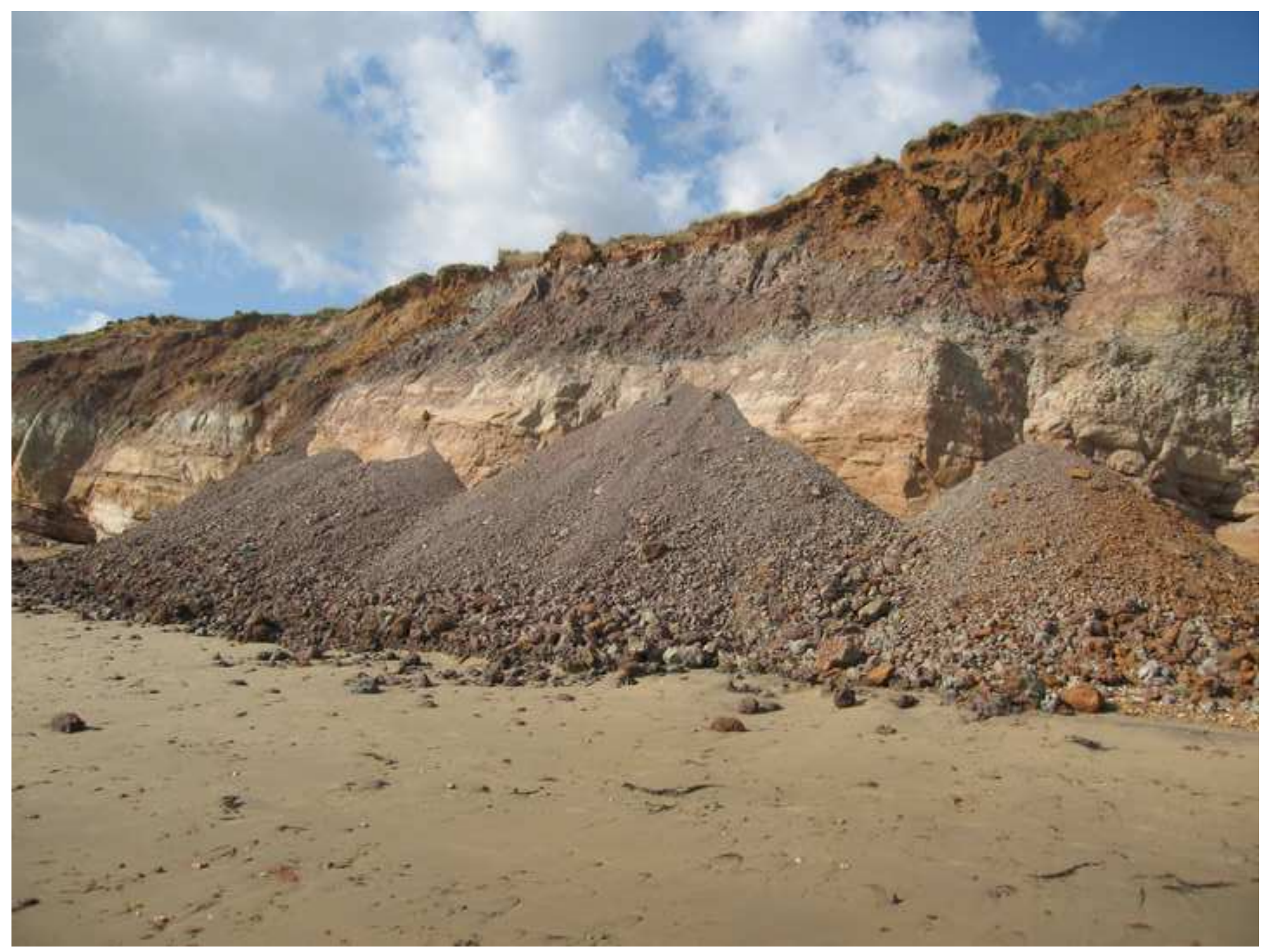


Click here to download high resolution image

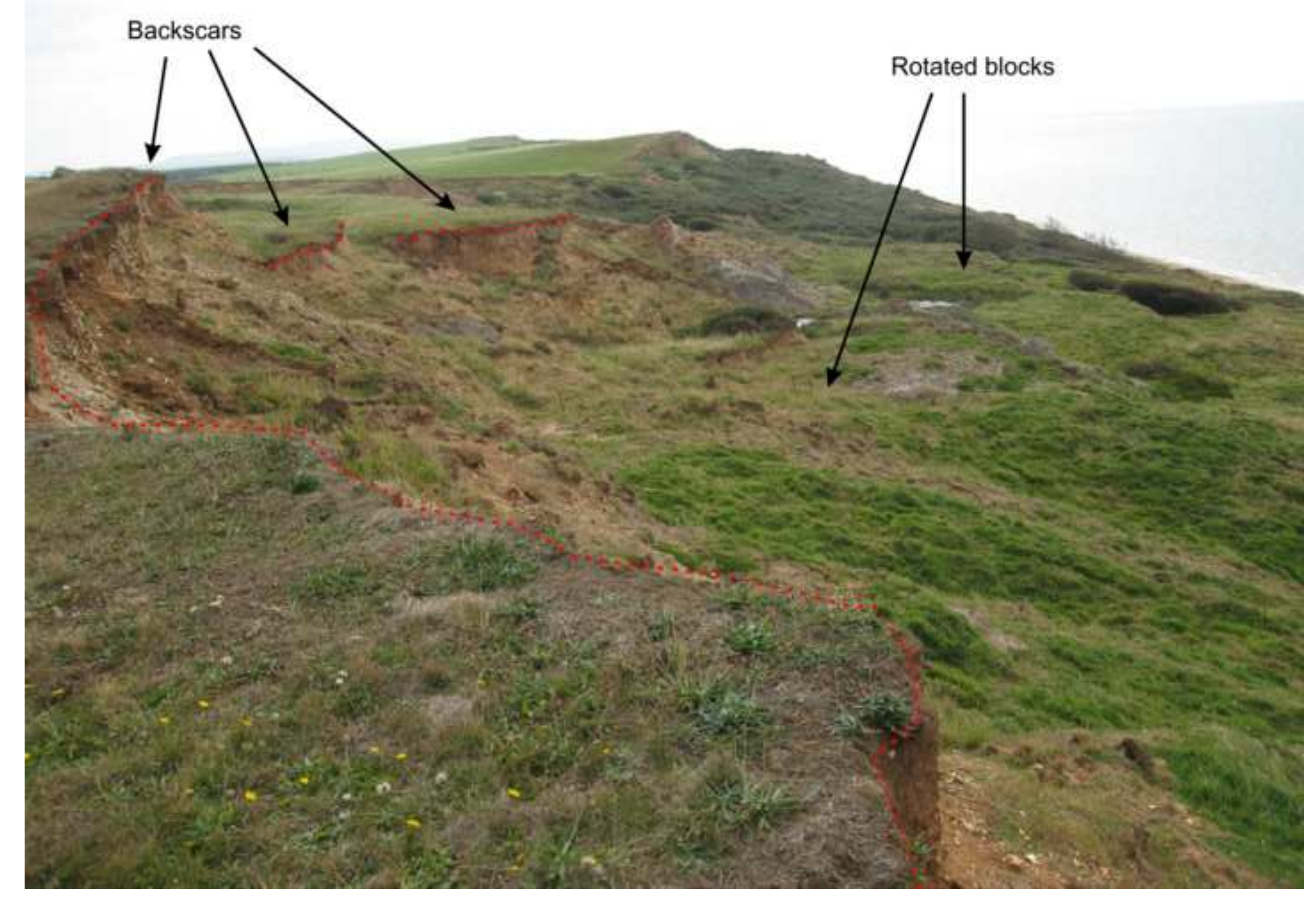

\section{Backscars}


Click here to download high resolution image

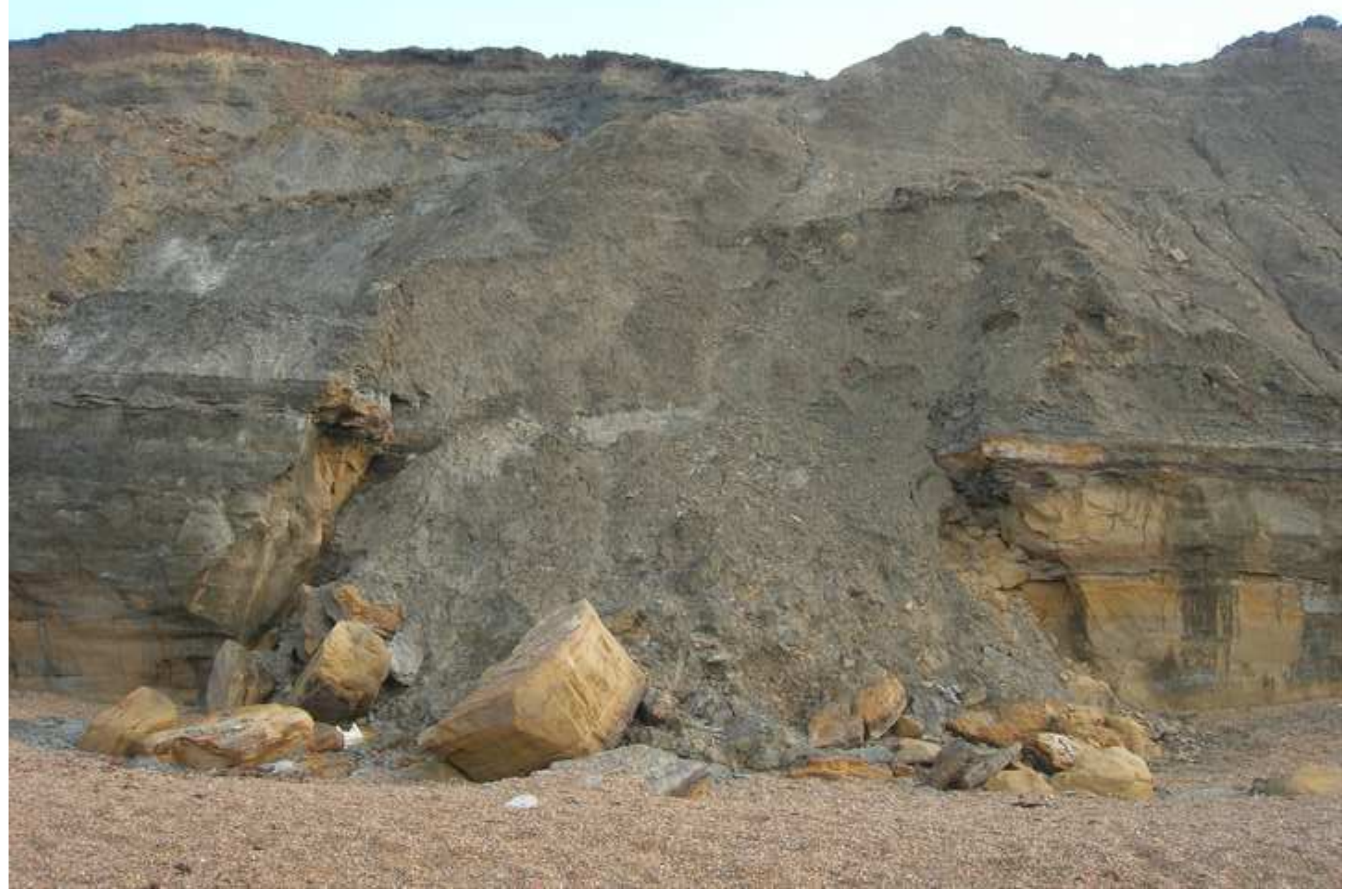


Click here to download high resolution image

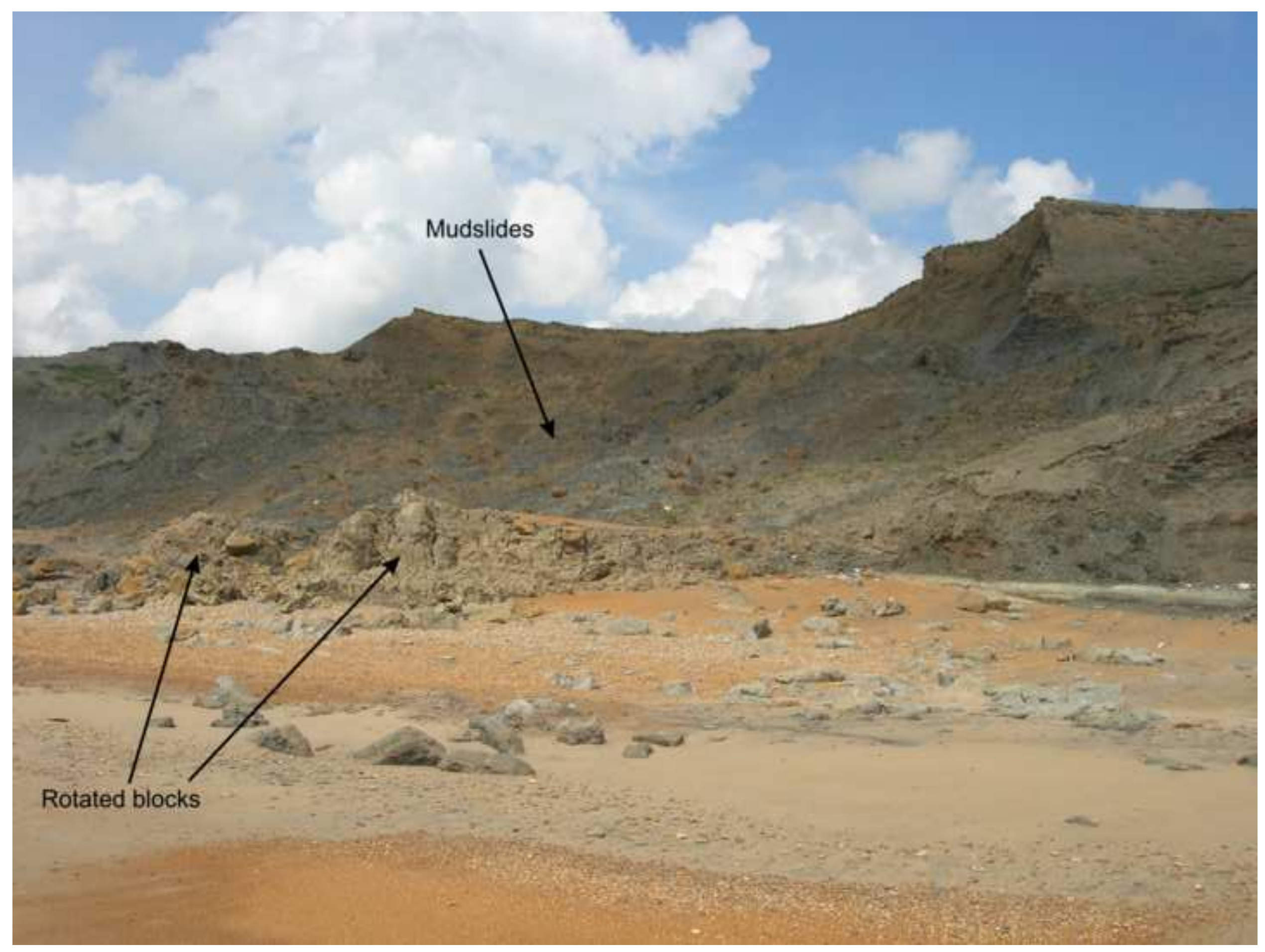

Figure 7 


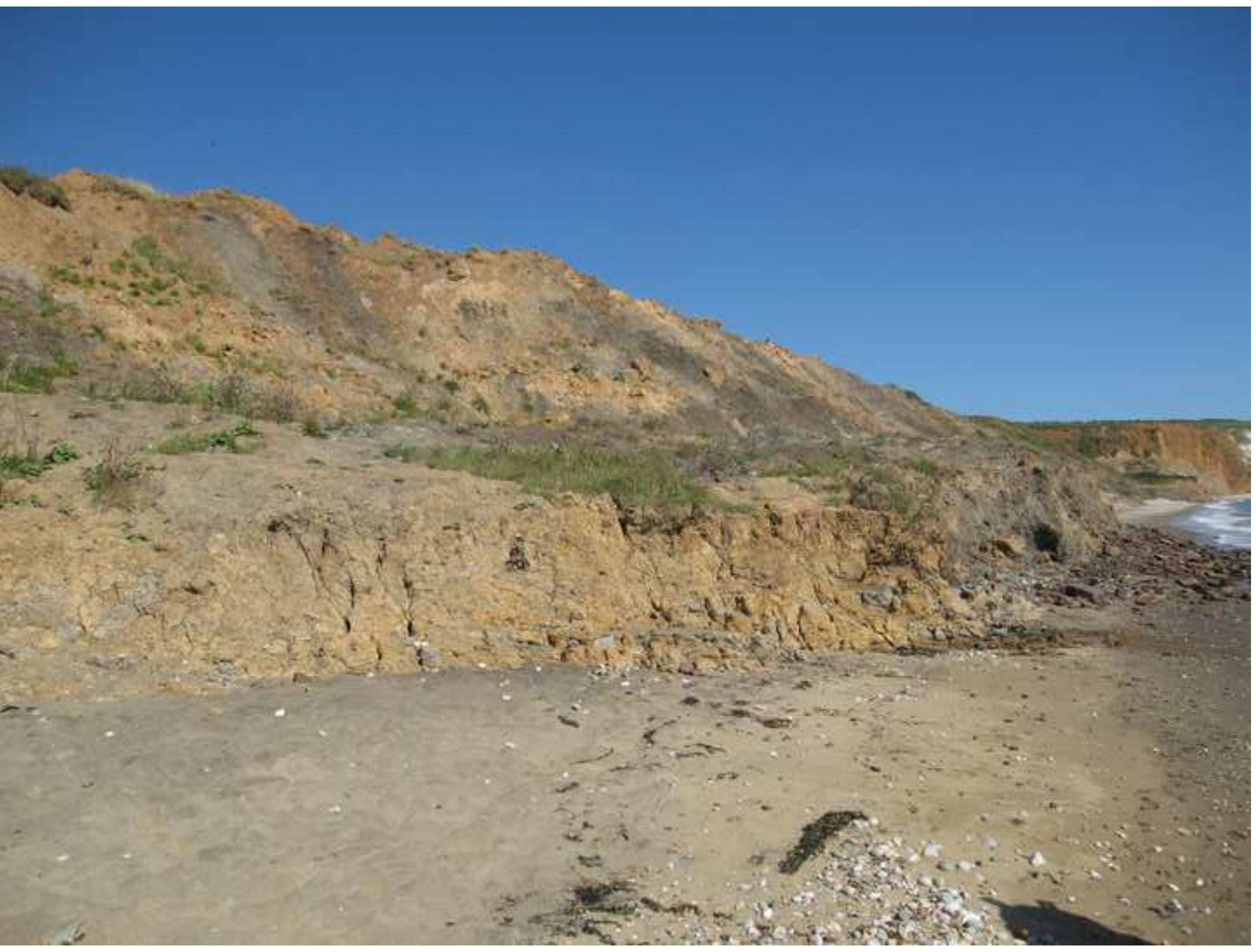


Figure 9
Click here to download high resolution image

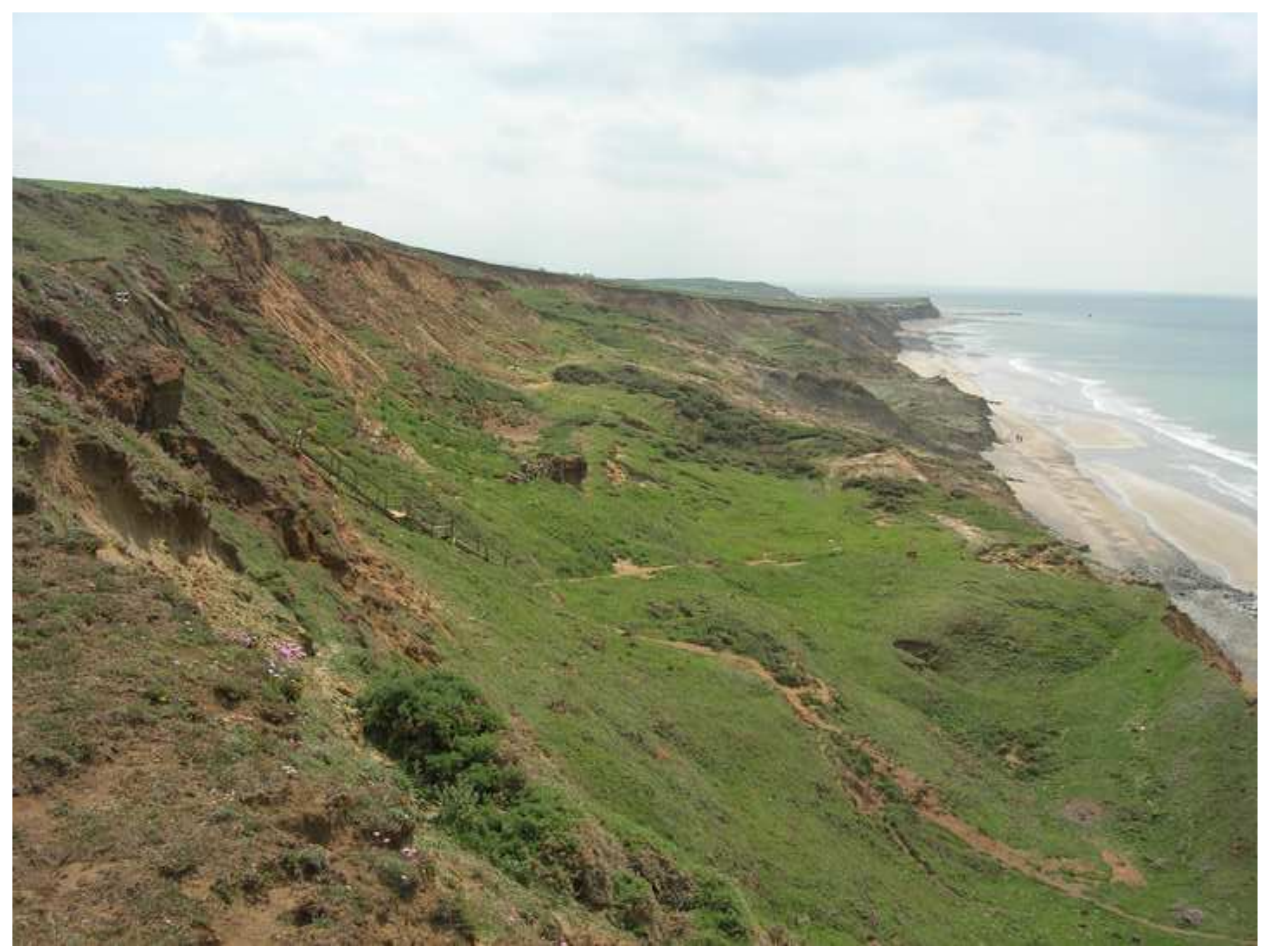


Click here to download high resolution image

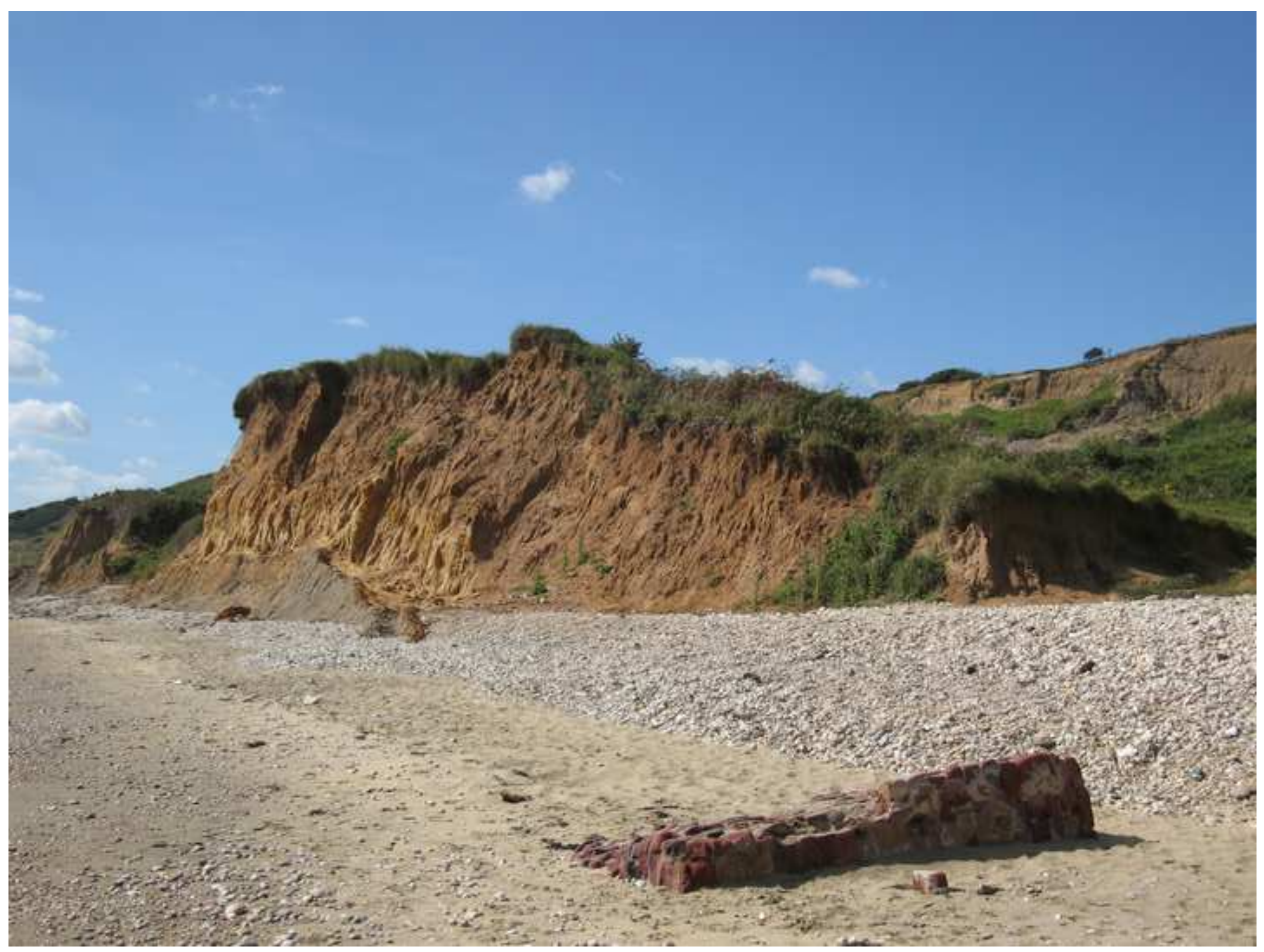


Click here to download high resolution image

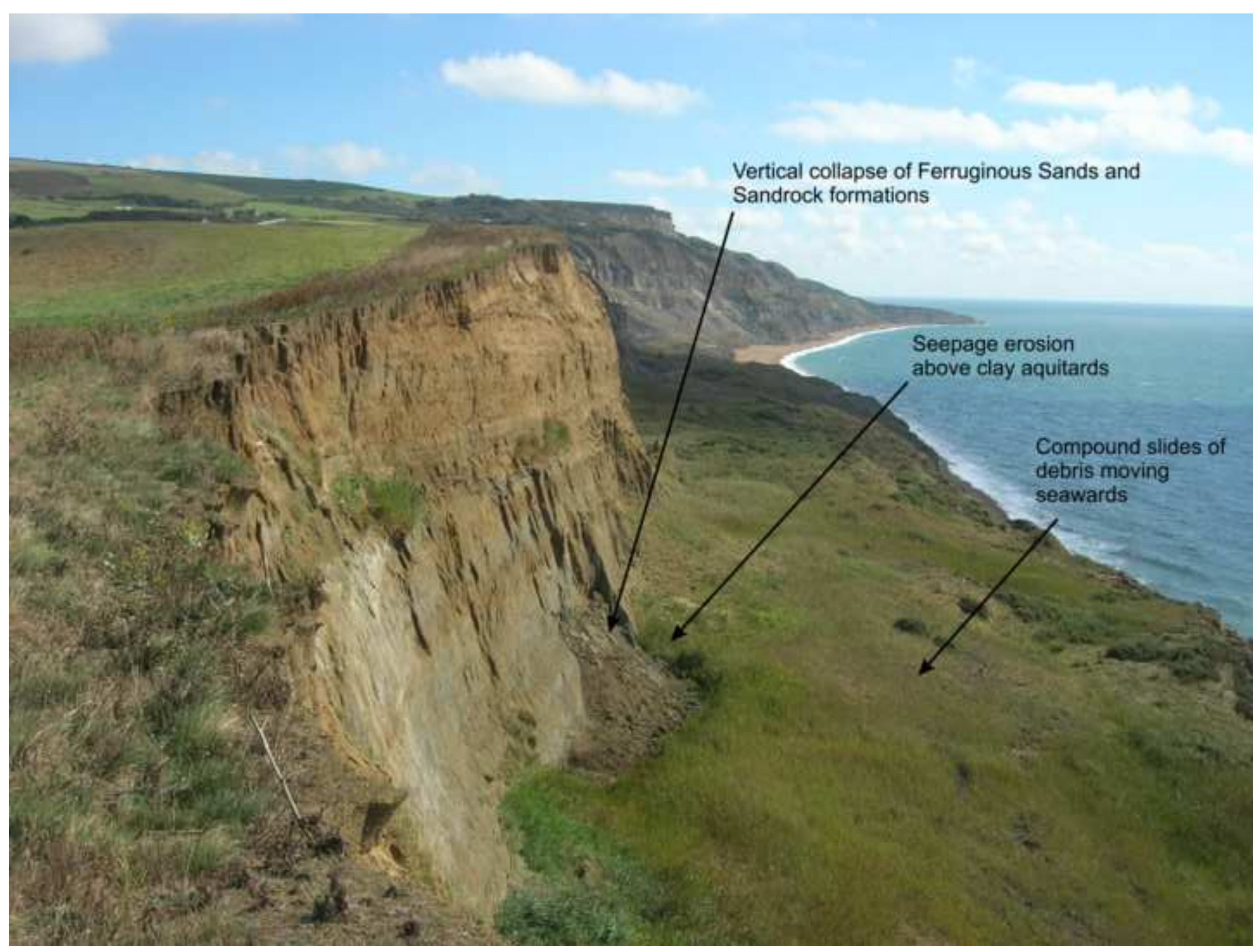




\section{Click here to download high resolution image}

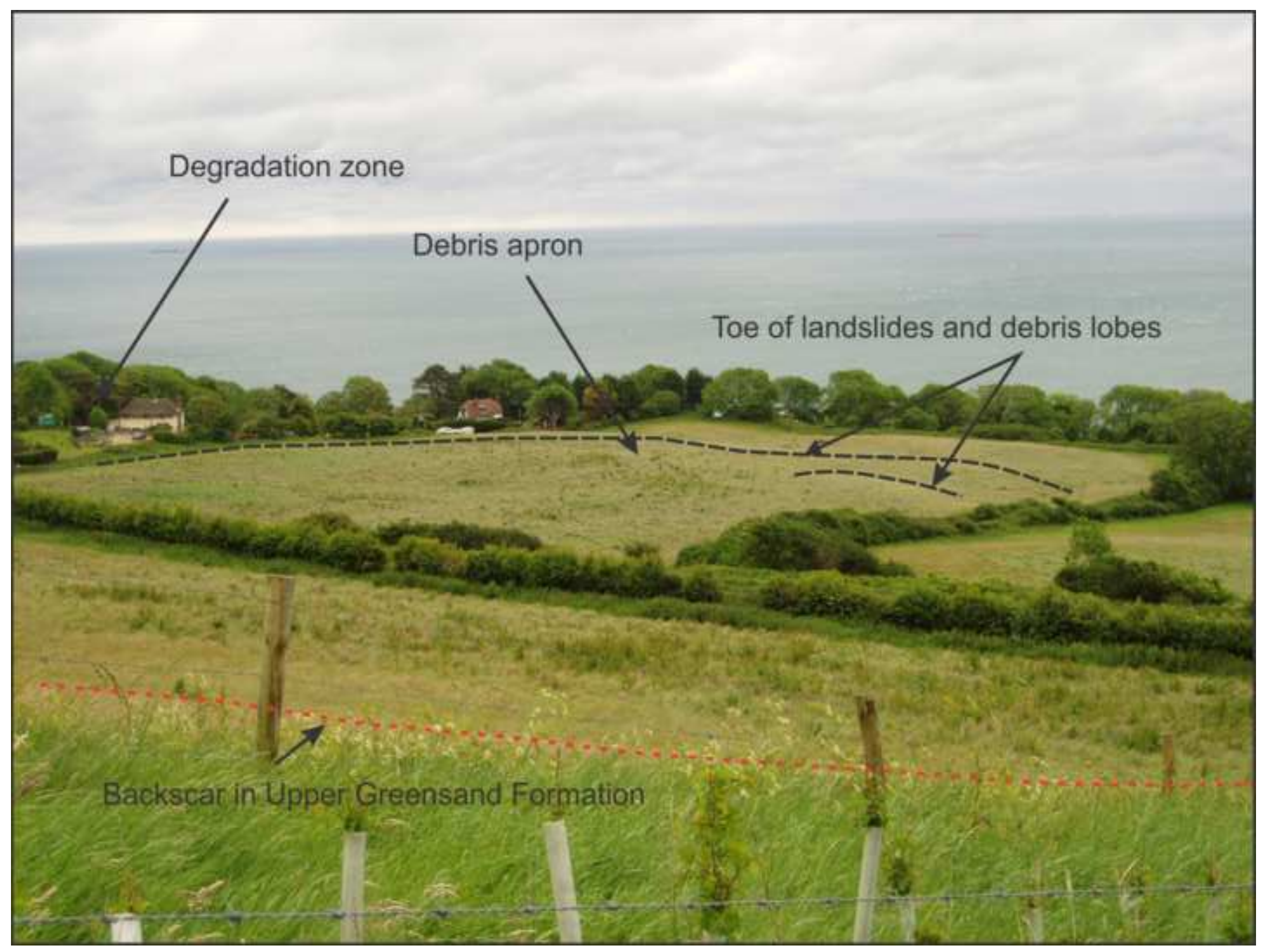

\section{Degradation zone}

\section{Debris apron}

Toe of landslides and debris lobes 
Click here to download high resolution image

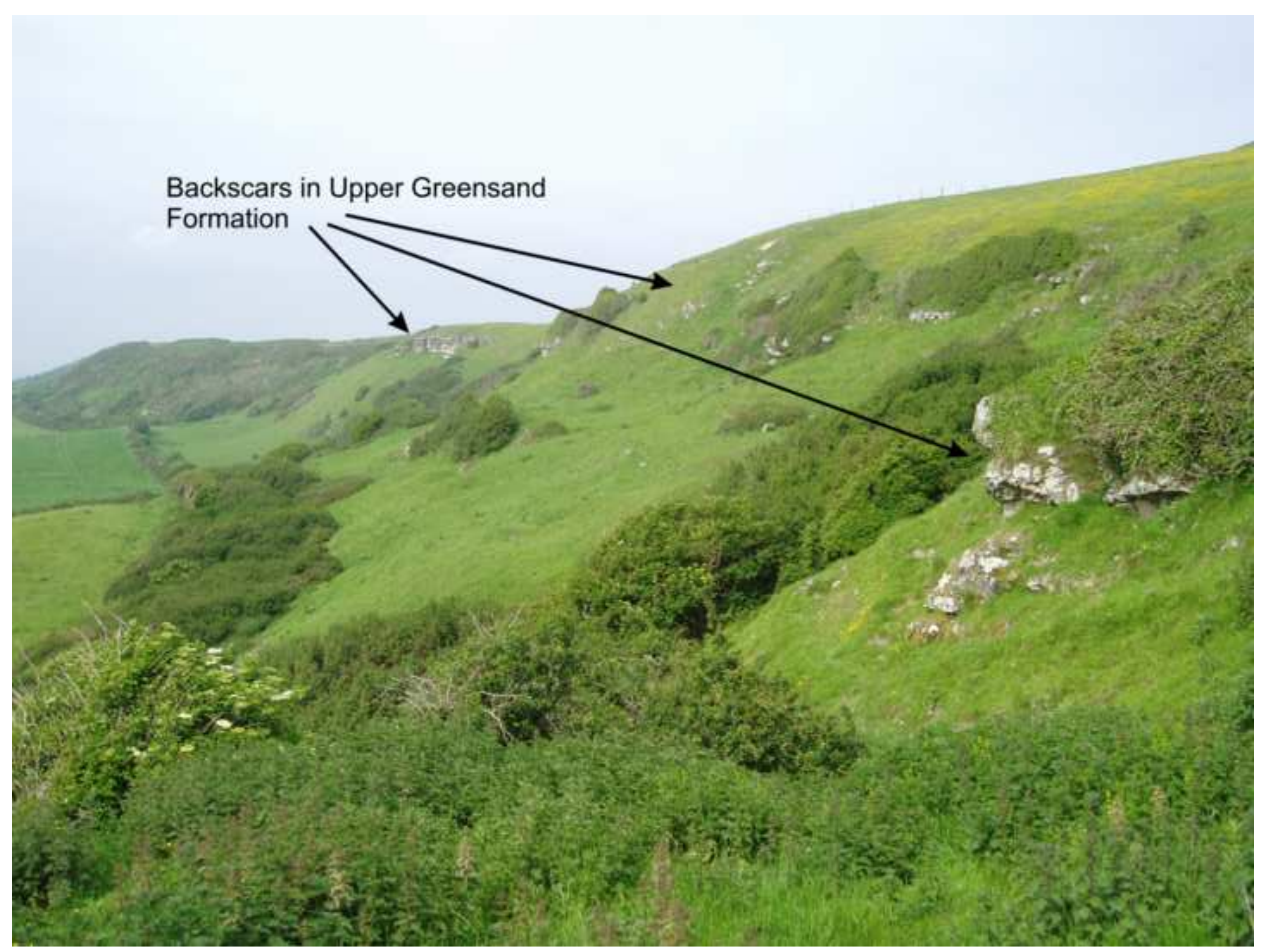

Backscars in Upper Greensand Formation 


\section{Click here to download high resolution image}

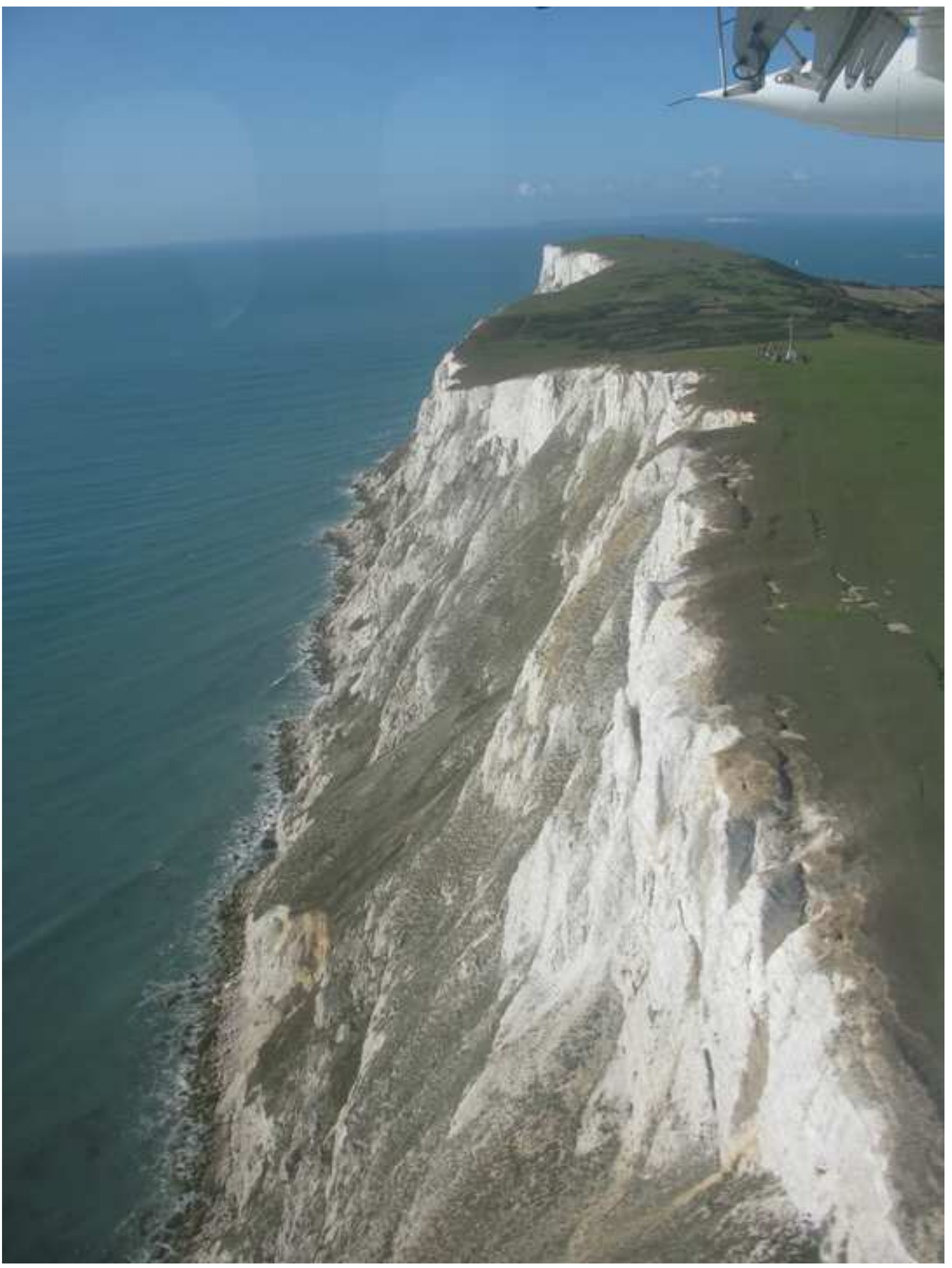

S.2. . 
Click here to download high resolution image
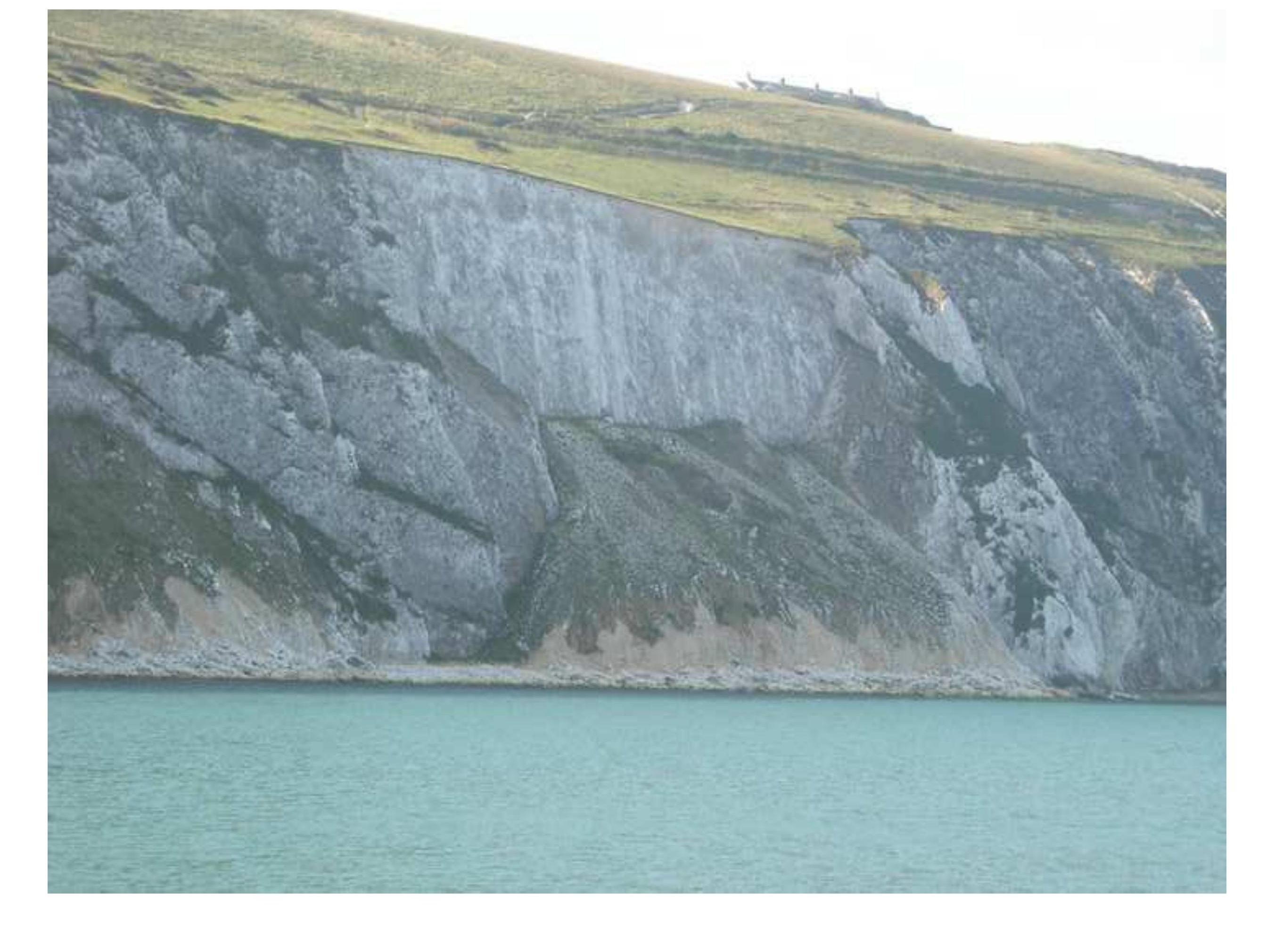
Click here to download high resolution image

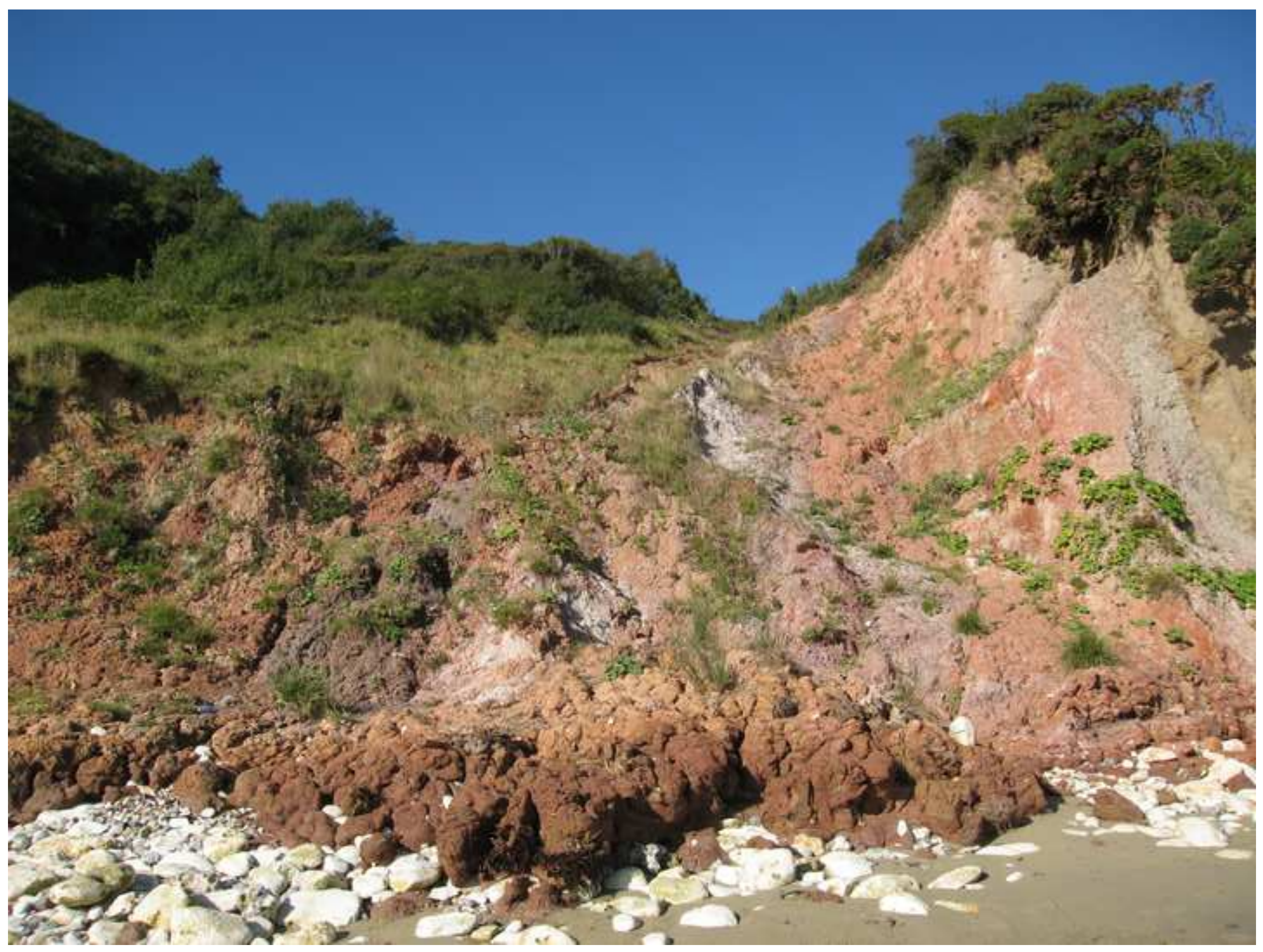




\section{Backscar}

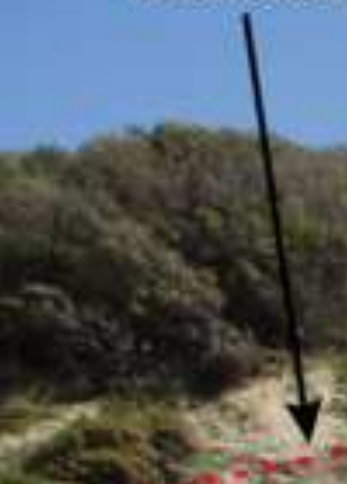

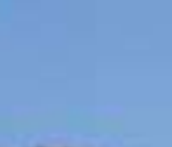

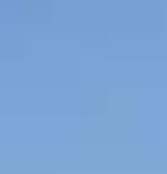

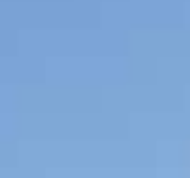
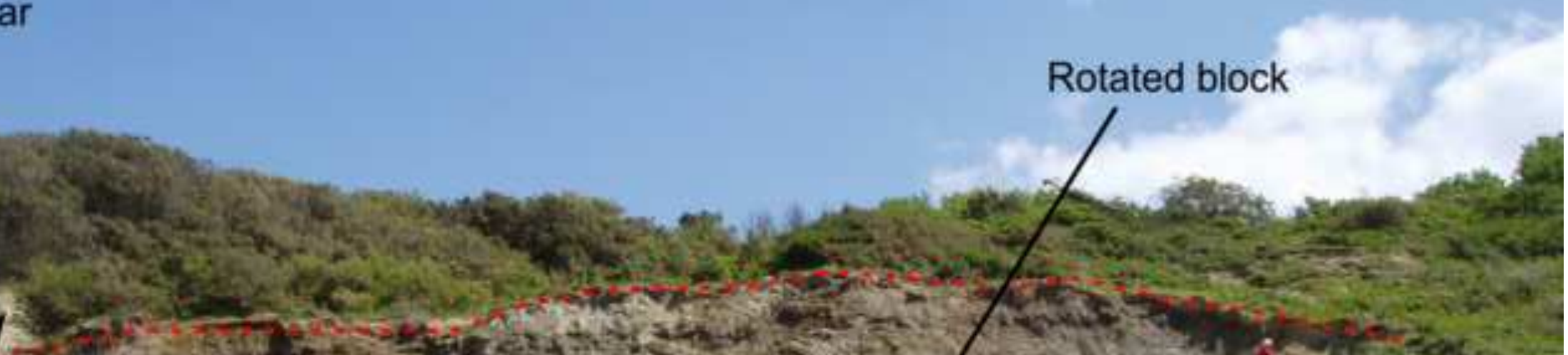

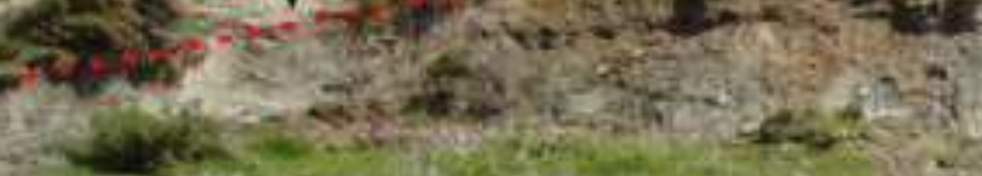

2 tow - Mudflows;

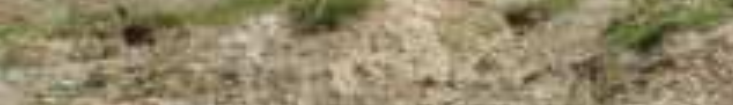

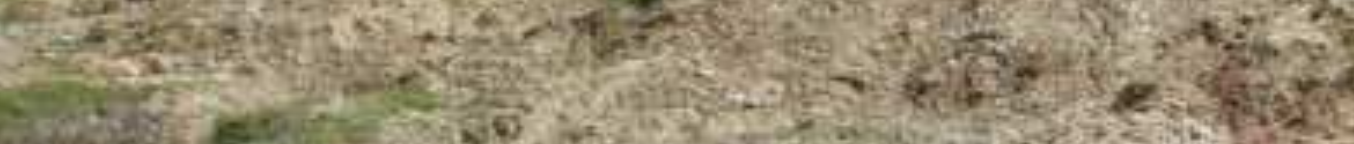

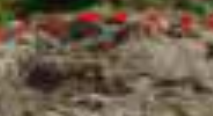

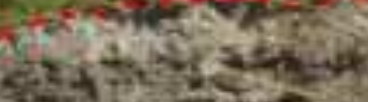
istioner.
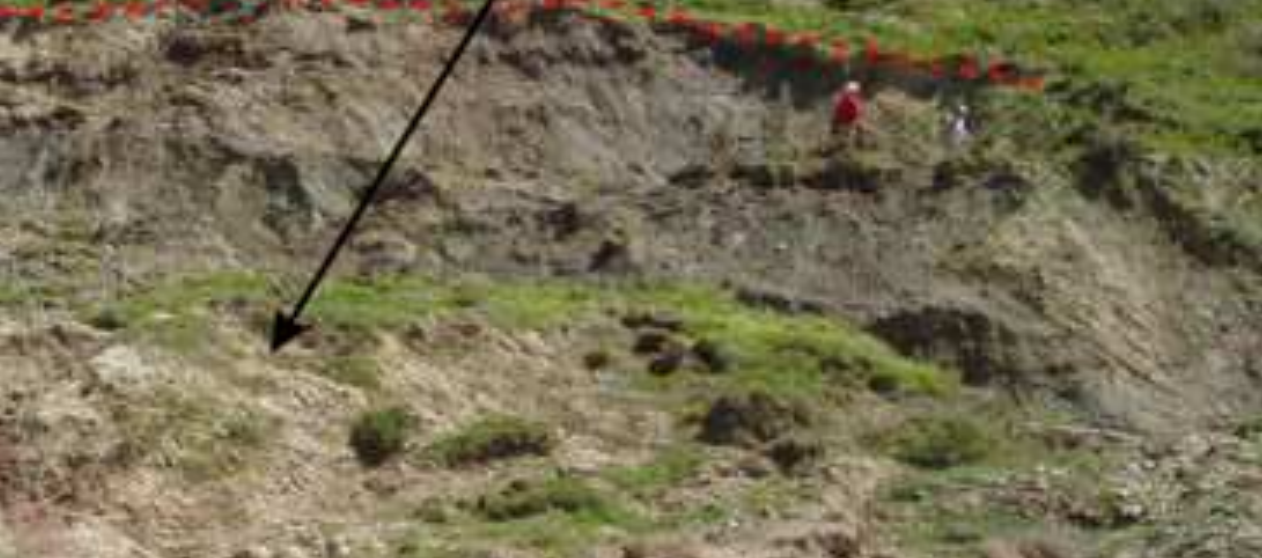

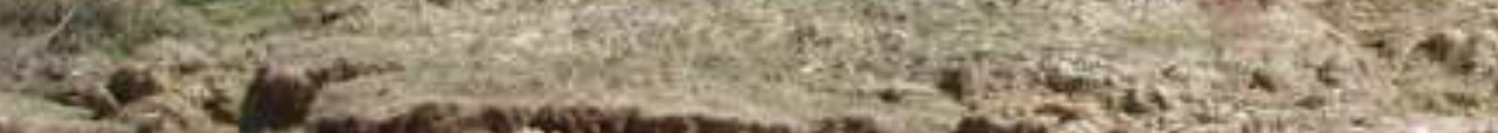

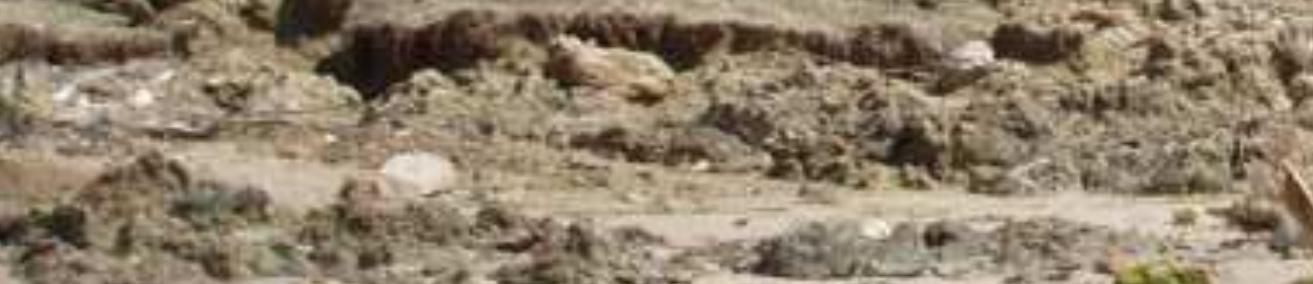

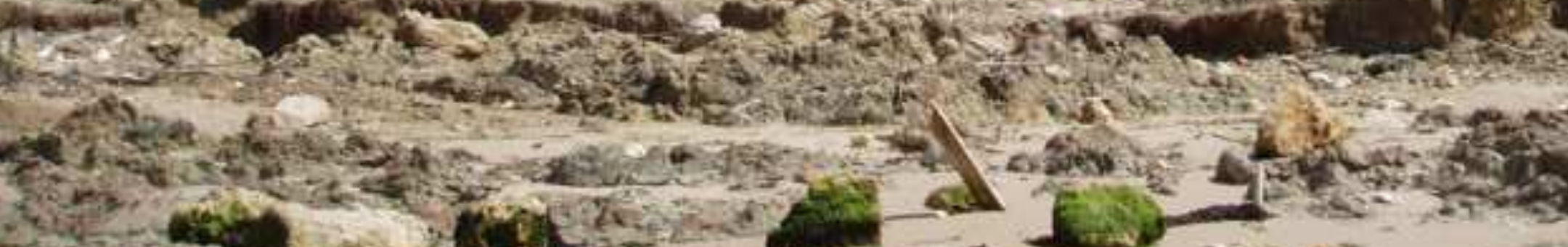

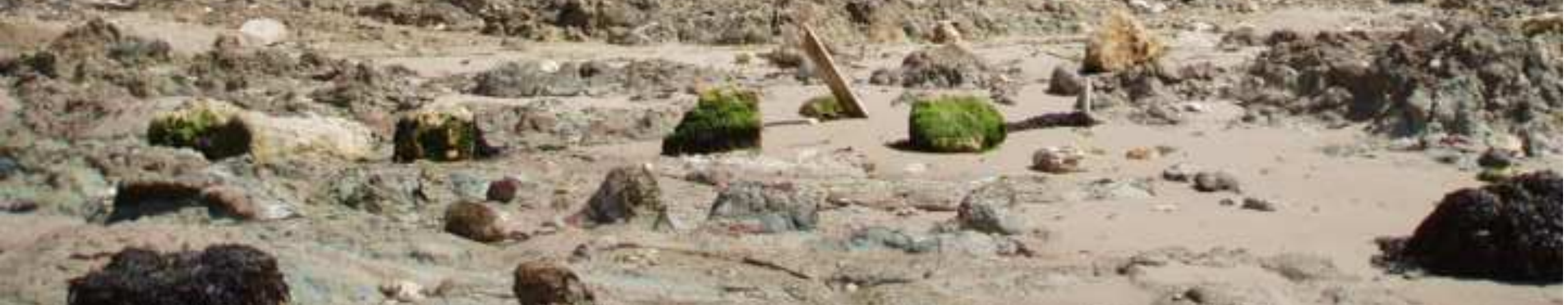


Click here to download high resolution image

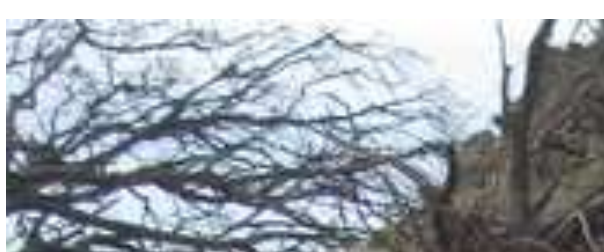

9.10\%:

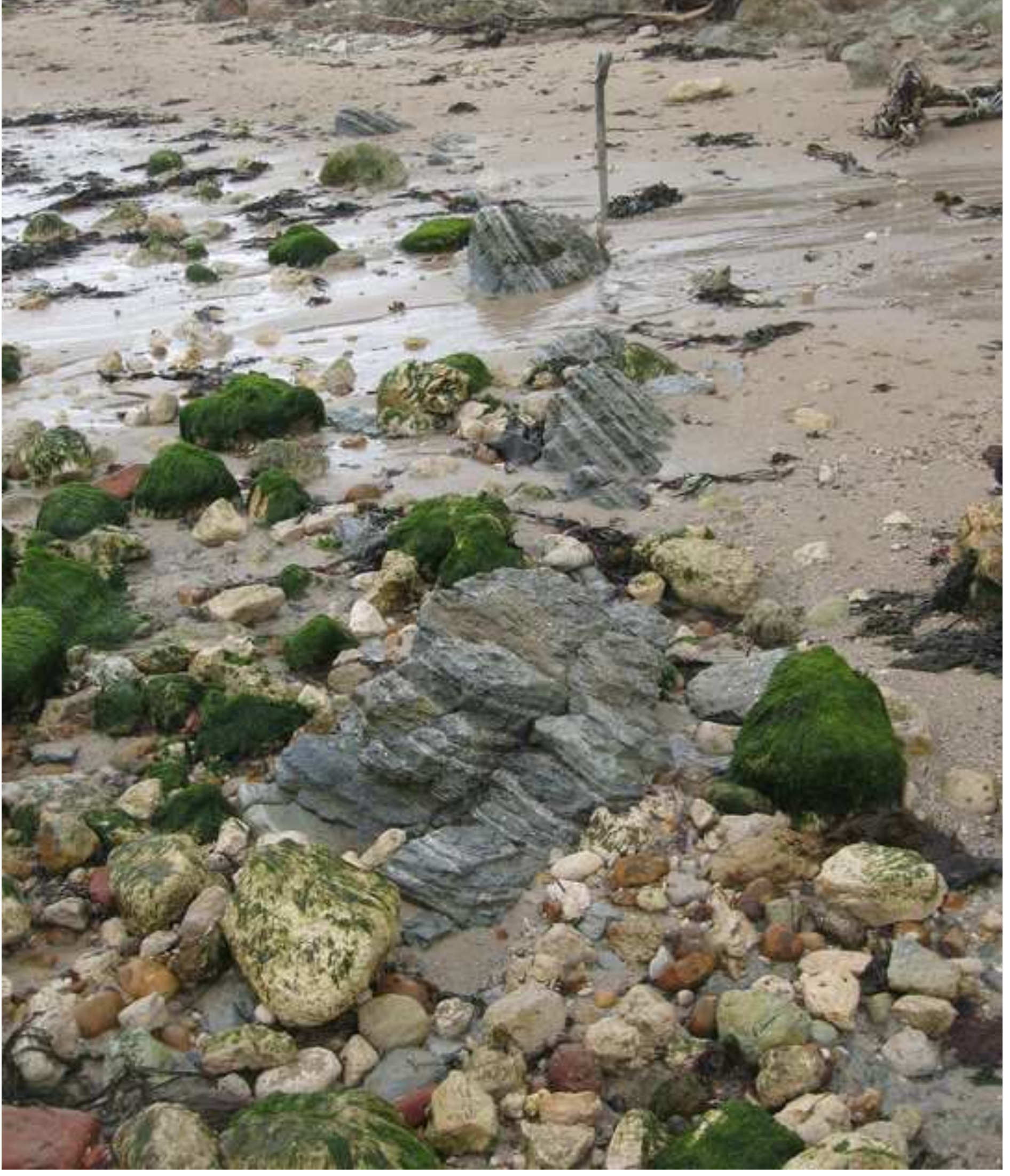

